Article

\title{
The Development of Nanoalumina-Based Cement Mortars for Overlay Applications in Concrete Floors
}

\author{
Jacek Szymanowski * and Łukasz Sadowski (i) \\ Faculty of Civil Engineering, Wroclaw University of Science and Technology, Wybrzeże Wyspiańskiego 27, \\ 50-370 Wrocław, Poland; lukasz.sadowski@pwr.edu.pl \\ * Correspondence: jacek.szymanowski@pwr.edu.pl; Tel.: +48-71-320-37-42
}

Received: 14 September 2019; Accepted: 18 October 2019; Published: 23 October 2019

\begin{abstract}
This article focuses on the development of nanoalumina-based cement mortars for overlay applications in concrete floors. It focuses on the effect of applying aluminum oxide $\left(\mathrm{Al}_{2} \mathrm{O}_{3}\right)$ nanopowder to the cement mortar used to make the overlay, on the adhesion of this overlay to concrete substrate and on its functional properties. It was claimed that the addition of $0.5 \%$ of $\mathrm{Al}_{2} \mathrm{O}_{3}$ nanopowder has a positive effect on the adhesion of the cement mortar used to make the overlay to the substrate made of concrete. The prior studies performed using scanning electron microscopy (SEM) confirmed that the reason for the improvement in adhesion is the fact that cement mortar used to make the overlay with the addition of $0.5 \%$ of $\mathrm{Al}_{2} \mathrm{O}_{3}$ nanopowder is less porous than the reference mortar within the interphase. The article concurs that the most favorable results, in terms of lower abrasion resistance and higher subsurface tensile strength of the cement mortar used to make the overlay, are mainly brought about by adding $0.5 \%$ of $\mathrm{Al}_{2} \mathrm{O}_{3}$ nanopowder.
\end{abstract}

Keywords: aluminum oxide nanopowder; cement mortar overlay; substrate; concrete floors; adhesion; functional properties

\section{Introduction}

In construction, in terms of durability, cement mortar used to make the overlay should primarily have an adequate adhesion to the concrete substrate [1-3]. According to [4-7], the pull-off adhesion of cement mortar used to make the overlay to the concrete substrate should be at least $0.5 \mathrm{MPa}$ for newly made overlays. As highlighted in [8], in the case of repaired concrete elements, the value of pull-off adhesions should be at least $2 \mathrm{MPa}$ and $1 \mathrm{MPa}$ for structural and nonstructural repairs, respectively. As stated in [9-12], the properties of the cement mortar used to make the overlay are strongly influenced by the porosity, microcracks, moisture content, absorption rate and morphology of the substrate. Thus, according to recent literature, in order to obtain this adhesion at an appropriate level, mechanical treatment of the concrete substrate surface is applied [13-15]. Although sandblasting seems to be the most advantageous for many surfaces [16], as demonstrated in [17] for layered cement composites, it is beneficial to use shot-blasting in order to most efficiently treat the concrete substrate. Furthermore, texturing the surface of a concrete substrate has recently gained more attention $[18,19]$. What is more, surface exposure of the coarse aggregate of the substrate, and strengthening of the surface of the concrete substrate, are frequently done [20-22]. Increasingly, various additives are also being used to modify the material of the cement mortar used to make the overlay [23-32]. For example, Luković et al. [33] recently used blast furnace slag to replace part of the Portland cement in repair overlay.

Moreover, for durability reasons, the cement mortar used to make the overlay should have suitable mechanical and functional properties. The mechanical properties include mainly the compressive and flexural strength. On the other hand, the functional properties include mainly subsurface tensile 
strength, abrasion resistance and hardness. Thus, additional treatments should be applied in in order to obtain the values of mechanical and functional properties at the desired levels. The literature also presents the use of polypropylene, steel, copper and basalt fibers in mortars and concretes to improve their abrasion resistance [34-37].

It seems that the material modification of the composition of the cement mortar used to make the overlay with mineral additives, with particular emphasis on nanoparticles, is reasonable [38-42]. The application of nanoparticles improves some of the properties of cement-based mortars, such as the corrosion protection of reinforcing steel [43] and the mitigation of the alkali-silica reaction [44]. There is hope that this approach can also successfully improve the adhesion of the cement mortar used to make the overlay to the concrete substrate, as well as improve its functional properties. Based on an analysis of the subject of the literature concerning, e.g., the application of nanoparticles as an addition to the cement mortar used to make the overlay [45-53], one can see opportunities to improve its adhesion with the substrate and improve its functional properties.

The results of research carried out by the authors of work [54] indicate that the modification of the composition of the cement mortar used to make the overlay by adding amorphous silicon oxide $\left(\mathrm{SiO}_{2}\right)$ nanospheres slightly increases its adhesion with the concrete substrate, and also significantly improves its functional properties. However, according to the authors of work [54], further research should primarily focus on the search for an additive that will improve the adhesion of the cement mortar used to make the overlay to the substrate more than the addition of $\mathrm{SiO}_{2}$ nanoparticles in the form of amorphous nanospheres. According to the authors, it is worth conducting research on the impact of the content of nanoparticles not used for this purpose; e.g., aluminum oxide $\left(\mathrm{Al}_{2} \mathrm{O}_{3}\right)$. Stefaniuk et al. [55] successfully evaluated the elastic properties of self-compacting concrete with $\mathrm{Al}_{2} \mathrm{O}_{3}$ nanoparticles. Chen et al. [56] studied the early hydration of calcium aluminate cement modified using $\mathrm{Al}_{2} \mathrm{O}_{3}$ nanoparticles. In regard to layered composites, the recently performed applications of adding $\mathrm{Al}_{2} \mathrm{O}_{3}$ nanoparticles have had a positive effect and allowed for an increase in the adhesion of epoxy resin to steel [57], had a positive effect on the adhesion of the geopolymer overlay to the concrete substrate [58], improved the adhesion of concrete to reinforcing steel [59] and had a positive effect on improving the strength parameters of epoxy adhesives in aluminum joints [60].

Considering the above, there has not yet been broader research on the effect of the modification of the material of cement mortar used to make the overlay using $\mathrm{Al}_{2} \mathrm{O}_{3}$ nanopowder on its adhesion with the concrete substrate. Moreover, the impact of the content of $\mathrm{Al}_{2} \mathrm{O}_{3}$ nanopowder is still unknown. To date, the effects of this nanopowder on the functional properties of the cement mortar used to make the overlay have not yet been studied. Therefore, the purpose of this article is to obtain the answer to the above questions. Hopefully, getting the answers for the mentioned questions will lead to the development of nanoalumina-based cement mortars for overlay applications in concrete floors.

\section{Materials and Methods}

\subsection{Concrete Substrate Mix Design and Preparation}

The tests were carried out on a model element with dimensions of $800 \times 800 \mathrm{~mm}^{2}$. This element was made of cement-based composites: an overlay made of cement mortar and a substrate made of concrete. The total thickness of this element was equal to $165 \mathrm{~mm}$ (Figure 1). The overlay of the element had a thickness of $40 \mathrm{~mm}$. The thickness of the substrate was equal to $125 \mathrm{~mm}$. 
(a) The concrete substrate treatment method

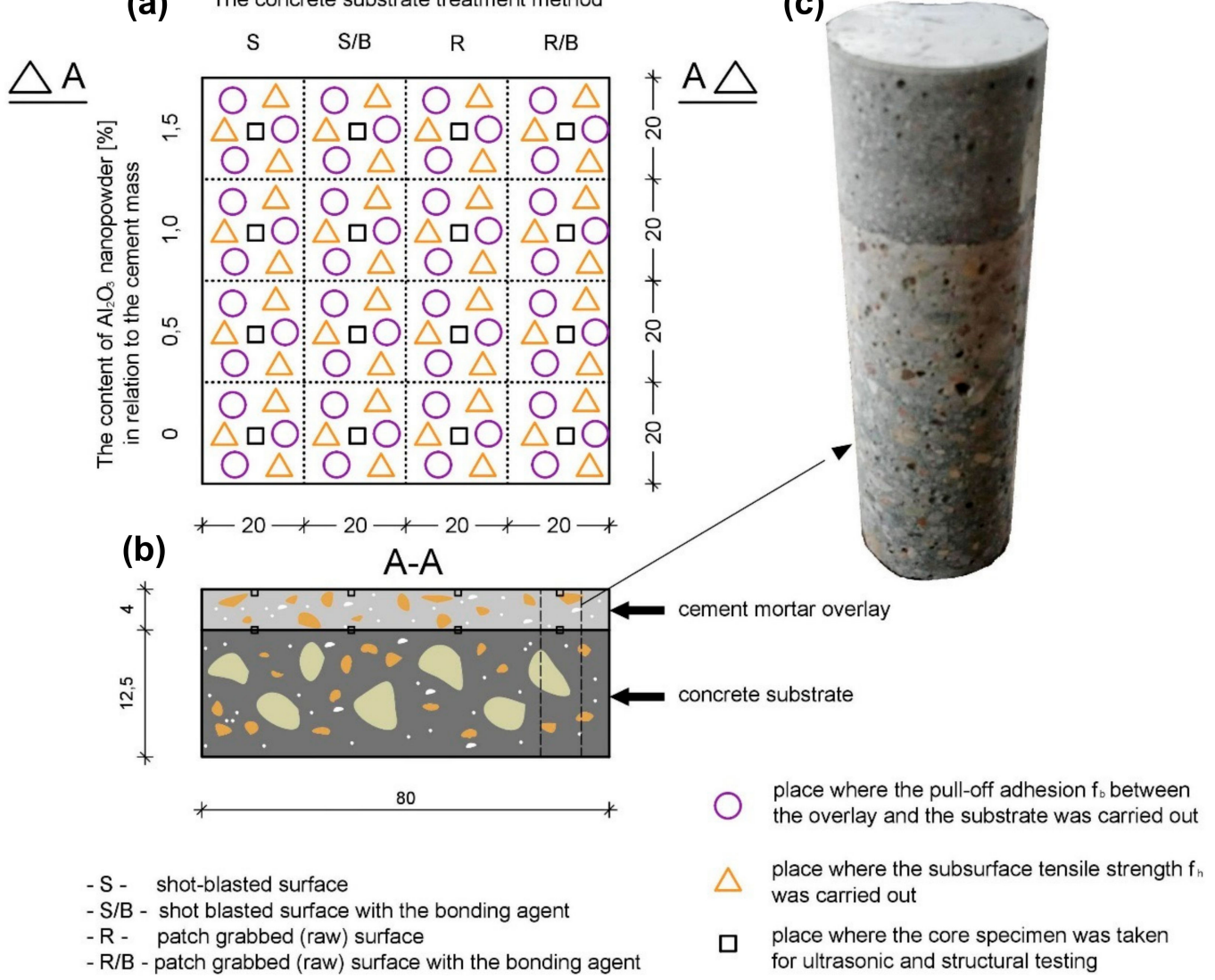

Figure 1. Model element made of cement-based composites: (a) view from the top, (b) cross-section and (c) view of the core specimen for structural testing (description in the text).

The substrate was made of concrete, with a water-cement ratio equal to 0.47 . The following materials were used to make the substrate (per $1 \mathrm{~m}^{3}$ ): $352.0 \mathrm{~kg}$ of Portland cement type CEM II A-LL 42.5 R (Cement Hranice, Italian Buzzi Unicem group, Hranice, Czech Republic); $165 \mathrm{~kg}$ of water; $40 \mathrm{~kg}$ of fly ash (Zespół Elektrociepłowni Wrocławskich "Kogeneracja S.A", Wrocław, Poland); $724.4 \mathrm{~kg}$ of fine aggregate with a bulk density of $2.62 \mathrm{~g} / \mathrm{cm}^{3}$ (Mineral mine WIKA, Paniowice, Poland); and $1086.6 \mathrm{~kg}$ of coarse aggregate with a maximum size of grain equal to $8 \mathrm{~mm}$ and a bulk density of $2.60 \mathrm{~g} / \mathrm{cm}^{3}$ (Mineral mine "Byczeń", Byczeń, Poland). In order to obtain a consistency class S3 (slump from $100-150 \mathrm{~mm}$ ) of the concrete $\mathrm{mix}, 2.0 \mathrm{~L} / \mathrm{m}^{3}$ of polycarboxylate-based plasticizer was used (Sika, Wroclaw, Poland). The density of this plasticizer was equal to $1.07 \mathrm{~g} / \mathrm{cm}^{3}$. The water-cement ratio was 0.5. The maturation conditions of the substrate were the ambient temperature equal to $20 \pm 3{ }^{\circ} \mathrm{C}$ and the humidity equal to $60 \% \pm 5 \%$. This concrete composition is commonly used to make substrates in layered elements in civil engineering (such as for example floors). After that, the surface of the concrete substrate was divided into four parts (Figure 1). Each of the parts was treated in different ways, which allowed four types of surfaces with different morphology to be obtained:

1. S-shot-blasted surface obtained after shot-blasting with removal of dust;

2. S/B - shot-blasted surface obtained after shot-blasting with removal of dust and the application of the bonding agent;

3. $\quad \mathrm{R}$-patch grabbed (raw) surface obtained after casting;

4. $\mathrm{R} / \mathrm{B}$ - patch grabbed (raw) surface obtained after casting and the application of the bonding agent.

As the bonding agent, the ready-made mix based on synthetic resin (Weber PRIMO, Saint-Gobain Construction, Polska sp. z o.o., Warsaw, Poland) was applied. The bonding agent was applied on the surface of the substrate $4 \mathrm{~h}$ before casting the material of cement mortar used to make the overlay. 


\subsection{Mix Design of the Cement Mortar Used to Make the Overlay and Its Preparation}

In this research, $\mathrm{Al}_{2} \mathrm{O}_{3}$ nanopowder (Sigma Aldrich, Poznan, Poland); Portland cement type CEM I $42.5 \mathrm{R}$ with a bulk density of $1.106 \mathrm{~g} / \mathrm{cm}^{3}$ containing $64.07 \% \mathrm{CaO}, 19.98 \% \mathrm{SiO}_{2}, 4.95 \% \mathrm{Al}_{2} \mathrm{O}_{3}, 2.66 \%$ $\mathrm{Fe}_{2} \mathrm{O}_{3}, 1.45 \% \mathrm{MgO}, 0.73 \% \mathrm{~K}_{2} \mathrm{O}$ and $0.18 \% \mathrm{Na}_{2} \mathrm{O}$ (Cementownia Górażdże Cement S.A. Heidelberg Cement Group, Górażdże, Poland); fine aggregate (sand) with a bulk density of $1.497 \mathrm{~g} / \mathrm{cm}^{3}$ (mineral mine "Margo", Mietkow, Poland); and polycarboxylate-based superplasticizer with a density of $1.080 \mathrm{~g} / \mathrm{cm}^{3}$ (Sika, Wroclaw, Poland) were used to make the cement mortar in the proportions given in Table 1. The water-binder ratio for this mortar was equal to 0.3 . The mixing procedure was as follows. The superplasticizer was added to the mixing. Then, $\mathrm{Al}_{2} \mathrm{O}_{3}$ nanopowder was added to the water and mix. Next the cement was added and mixed for $45 \mathrm{~s}$ using the rotation speed equal to $140 \mathrm{rpm}$ (automatic mixer was used). Then sand was added and all was mixed for another $45 \mathrm{~s}$ using the same rotation speed. After that, the mix was mixed again for $18 \mathrm{~s}$ using the rotation speed equal to $285 \mathrm{rpm}$. After casting the cement mortar used to make the overlay, the maturation conditions were $21 \pm 1{ }^{\circ} \mathrm{C}$ and $60 \% \pm 5 \%$ humidity.

Table 1. Mix designs of cement mortars used to make the overlays with the addition of aluminum oxide $\left(\mathrm{Al}_{2} \mathrm{O}_{3}\right)$ nanopowder (per $100 \mathrm{~g}$ of sand).

\begin{tabular}{cccccc}
\hline $\begin{array}{c}\text { Content of } \mathrm{Al}_{2} \mathbf{O}_{3} \\
\text { Nanopowder }\end{array}$ & $\begin{array}{c}\mathrm{Al}_{2} \mathbf{O}_{3} \\
\text { Nanopowder }\end{array}$ & $\begin{array}{c}\text { Cement type } \\
\text { CEM I 42.5 R }\end{array}$ & $\begin{array}{c}\text { Fine Aggregate } \\
\text { (Sand) }\end{array}$ & $\begin{array}{c}\text { Polycarboxylate-Based } \\
\text { Superplasticizer }\end{array}$ & Water \\
\hline $\begin{array}{c}\text { \% of the mass } \\
\text { of cement) }\end{array}$ & & & $(\mathrm{g})$ & & \\
\hline 0 & 0 & 73.30 & 100.00 & 0.37 & 22.00 \\
0.5 & 0.37 & 73.30 & 100.00 & 0.37 & 22.00 \\
1.0 & 0.73 & 73.30 & 100.00 & 0.37 & 22.00 \\
1.5 & 1.10 & 73.30 & 100.00 & 0.37 & 22.00 \\
\hline
\end{tabular}

2.3. Determination of the Particle Size Distribution of Nanopowder Using Transmission Electron Microscopy (TEM)

The morphology of the $\mathrm{Al}_{2} \mathrm{O}_{3}$ nanopowder was examined with transmission electron microscopy (TEM) imaging using a Hitachi H-800 electron microscope (Hitachi, Tokyo, Japan). The powder was suspended in deionized water and macroscopic aggregates were ultrasonically partitioned for $1 \mathrm{~s}$. The solution was immediately put on the standard carbon-on-copper supporting grids with a volume of $4 \mu \mathrm{L}$, drained of most liquid with filtering paper, then air dried for $1 \mathrm{~h}$. Observations were made in standard bright-field mode, using an accelerating voltage of $150 \mathrm{kV}$ and an EMSIS Quemesa CCD camera (EMSIS GmbH, Muenster, Germany).

\subsection{Determination of the Consistency and Bulk Density of Fresh Mortars}

Before laying the cement mortars used to make the overlay, their consistency was determined using a Novikow cone (MERAZET S. A., Poznań, Poland) according to [61]. The fresh mortar was placed in the measuring vessel and the metal cone was placed over the mortar surface (the vertex of the cone touched the surface) Then the metal cone was falling vertically for $10 \mathrm{~s}$. After this time, the measurements were taken from the scale on the side surface of the cone. The measurement was repeated three times. In order to determine the bulk density of the fresh mortar according to standard [62], the fresh mortar was placed in the mold with specific volume and mechanically compacted and weighted. Then the bulk density was calculated. The measure of bulk density was taken three times. The setting times of fresh mortar were carried out using Vicat apparatus (MERAZET S. A., Poznań, Poland) according to standard [63]. 


\subsection{Determination of the Mechanical Properties and Porosity of Hardened Cement Mortars}

According to [64], 6 samples with size of $40 \times 40 \times 160 \mathrm{~mm}^{3}$ were concreted from each mix in order to determine the mechanical properties and porosity of hardened cement mortars. Among others, the total porosity $p$, the compressive strength $f_{\mathrm{c}}$ and flexural strength $f_{\mathrm{ct}}$ were determined. The samples were stored at $21 \pm 1{ }^{\circ} \mathrm{C}$ and humidity up to $90 \%$ and tested after 28 days. First, flexural strength tests were carried out on six samples with dimensions $40 \times 40 \times 160 \mathrm{~mm}^{3}$. Then 12 halves of these samples were used for compressive strength tests ( 6 samples with dimensions $40 \times 40 \times 80 \mathrm{~mm}^{3}$ ) and to determine the total porosity of hardened mortars ( 6 samples with dimensions $40 \times 40 \times 80 \mathrm{~mm}^{3}$ ). The total porosities $p$, were determined using a Le Chatelier volume vessel according to Equation (1):

$$
p=\frac{\rho-\rho_{0}}{\rho} 100
$$

$\rho$-density $\left(\mathrm{kg} / \mathrm{cm}^{3}\right), \rho_{0}$ - bulk density $\left(\mathrm{kg} / \mathrm{cm}^{3}\right)$.

\subsection{Determination of the Pull-Off Adhesion of the Cement Mortars Used to Make the Overlays to the Concrete Substrate}

After 28 days, pull-off adhesion $f_{\mathrm{b}}$ tests were carried out using the pull-off method according to [65]. On Figure 2 the scheme of this method has been presented. The procedure is as follows: the drill of the core in the cement mortar is used to make the overlay with a diameter $D_{\mathrm{f}}=50 \mathrm{~mm}$ and $5 \mathrm{~mm}$. below overlay depth is performed, then the steel disc is glued to the overlay. Next, the steel disc is pulled off the substrate together with pulling off strength measuring. The loading rate should be equal to $0.05 \mathrm{MPa} / \mathrm{s}$. The pull-off adhesion $f_{\mathrm{b}}$ between the cement mortar used to make the overlay and the concrete substrate was calculated according to Equation (2):

$$
f_{b}=\frac{4 F_{b}}{\pi D_{f}^{2}}
$$

$F_{b}$-failure force $(\mathrm{N}), D_{f}$-the diameter of the core $(\mathrm{m})$.

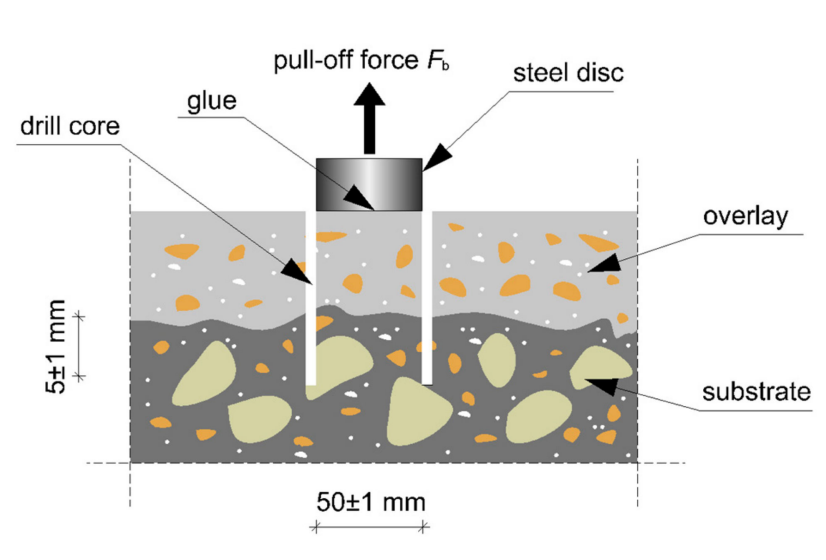

(a)

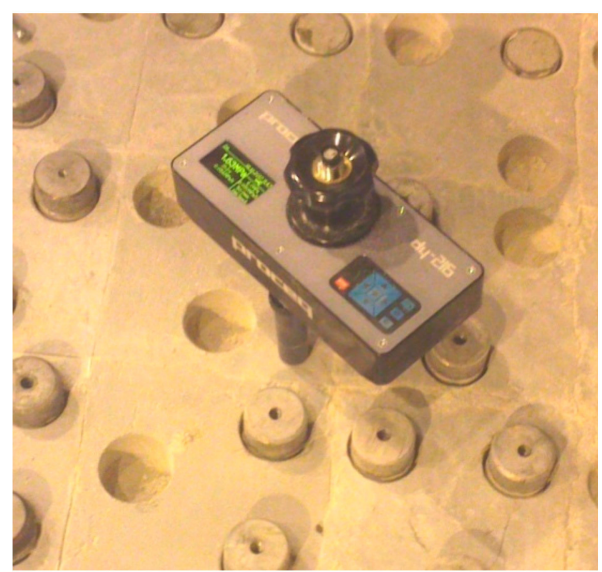

(b)

Figure 2. The pull-off method: (a) the scheme and (b) the view of test stand.

2.7. Determination of the Course of the Longitudinal Velocity of the Ultrasonic Wave along the Thickness of the Cement Mortar Used to Make the Overlay

From each mortar, one core sample with a diameter of $50 \mathrm{~mm}$ was taken in order to determine the course of the longitudinal velocity of the ultrasonic wave $c_{\mathrm{L}}$ along the thickness of the cement mortar used to make the overlay. Measuring points were marked on the lateral surfaces of these 
core samples at a spacing of $5 \mathrm{~mm}$ (Figure 3). Special ultrasound heads (Proceq AG, Schwerzenbach, Switzerland) with a frequency of $40 \mathrm{kHz}$ were employed. These heads had a point contact with the test surface and are described in detail in [66]. Classical ultrasonic heads do not allow one to observe properly, the course of the longitudinal velocity of the ultrasonic wave $c_{\mathrm{L}}$ along the thickness of the cement mortar [67-71]. Recently, this kind of head has been increasingly adopted to test cement-based materials [72,73].

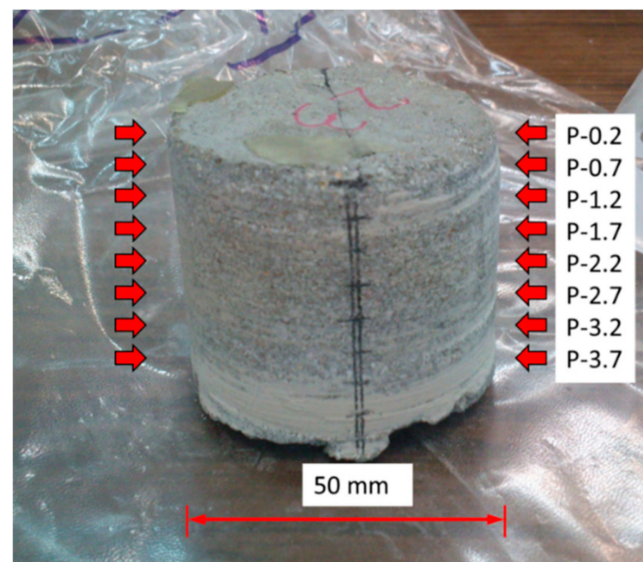

(a)

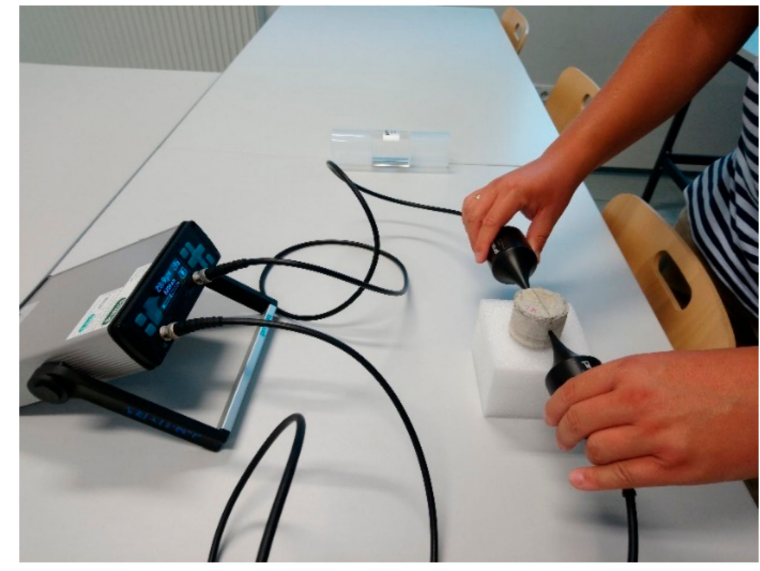

(b)

Figure 3. The ultrasonic method: (a) the arrangement of measuring points on a core sample for testing the longitudinal velocity of the ultrasonic wave $c_{\mathrm{L}}$ along the thickness of the cement mortar used to make the overlay; (b) the view of the core sample during the test.

\subsection{Determination of the Abrasion Resistance of Cement Mortars}

For each mortar, three samples measuring $71 \times 71 \times 71 \mathrm{~mm}^{3}$ were prepared in order to test their abrasion resistance according to [74]. The abrasion resistance was measured as volume loss or mass loss after 16 cycles of abrasion on Boehme (FORM+TEST Seidner\&Co. GmbH, Riedlingen, Germany) wheel. The samples were fastened and loaded with a force of $294 \pm 3 \mathrm{~N}$ (after each cycle the sample was turned at 90 degrees).

\subsection{Determination of the Subsurface Tensile Strength and Subsurface Hardness of Cement Mortars}

According to [65], the subsurface tensile strength $f_{\mathrm{h}}$ of the cement mortar used to make the overlay was determined using the pull-off method on the surface of the overlay. According to [75], the subsurface hardness was determined using the sclerometric method. For subsurface hardness testing, the Schmidt hammer type N (Proceq AG, Schwerzenbach, Switzerland) was used. In each measuring point at least 9 measurements were taken.

\subsection{Determination of the Microstructure of the Samples Using a Scanning Electron Microscope (SEM)}

Then, from each mortar, 1 cubic sample of size $11 \times 11 \times 11 \mathrm{~mm}^{3}$ was taken from the subsurface zone of the cement mortar used to make the overlay. Consequently, 1 cubic sample with the same dimensions was prepared from the interphase zone between the cement mortar used to make the overlay and the concrete substrate. These samples were used for microstructural tests using a scanning electron microscope (SEM, JEOL, Tokyo, Japan). The procedure of obtaining samples was as follows: first, the drill core with a diameter of $50 \mathrm{~mm}$ was created in samples (Figure 1). Then, cubic samples were cut using table diamond saw. In order to analyze the microstructure of mortars, the JEOL SEM model JSM-6610A (JEOL, Tokyo, Japan) was used. It was equipped with a tungsten cathode (Tungsten Hairpin Filament). A material contrast mode of the backscattered electron (BSE, JEOL, Tokyo, Japan) detector was applied. The BSE detector had an accelerating voltage equal to $20 \mathrm{kV}$ and a beam current of $40 \mathrm{nA}$ at the working distance of $10 \mathrm{~mm}$. The method of segmentation of pores with cement paste is 
based on analysis of area segmented on BSE images at different threshold levels [76]. As the threshold level increases, the area inside the pores increases, followed by pixels near the pore boundary. When the threshold level reaches a critical level, there is a significant increase in volume segmented in the BSE image around the pores. This critical level can be assumed as a threshold level for pores. It can be determined on the cumulative grayscale histogram near the inflection of the cumulative curve as the intersection point between two straight lines.

\section{Results and Analysis}

\subsection{The Particle Size Distribution of Nanopowder Using Transmission Electron Microscopy (TEM)}

Figure 4 presents an image of the $\mathrm{Al}_{2} \mathrm{O}_{3}$ nanopowder particles, which was made using a TEM and the particle size distribution of $\mathrm{Al}_{2} \mathrm{O}_{3}$ nanopowder. Nanopowder containing $99.8 \%$ of $\mathrm{Al}_{2} \mathrm{O}_{3}$ with a mean particle size below $50 \mathrm{~nm}$ was used. The particle size distribution is based on 50 randomly chosen particles. The longest diagonal was assumed as particle size.

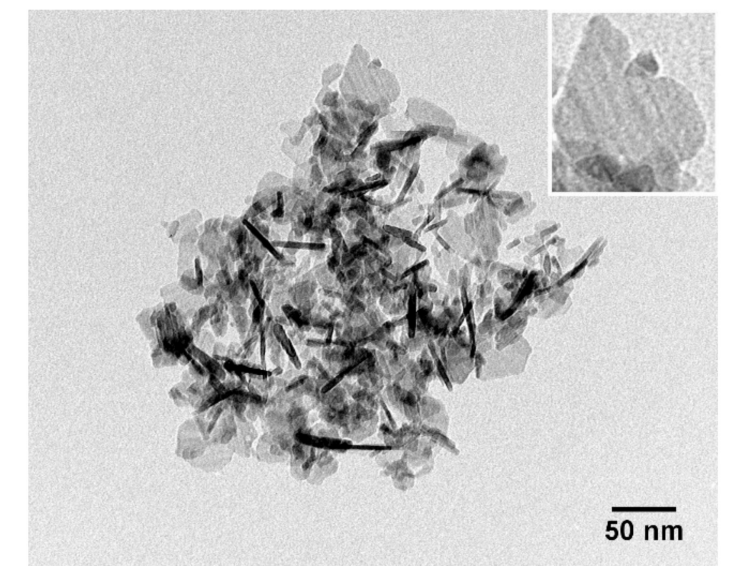

(a)

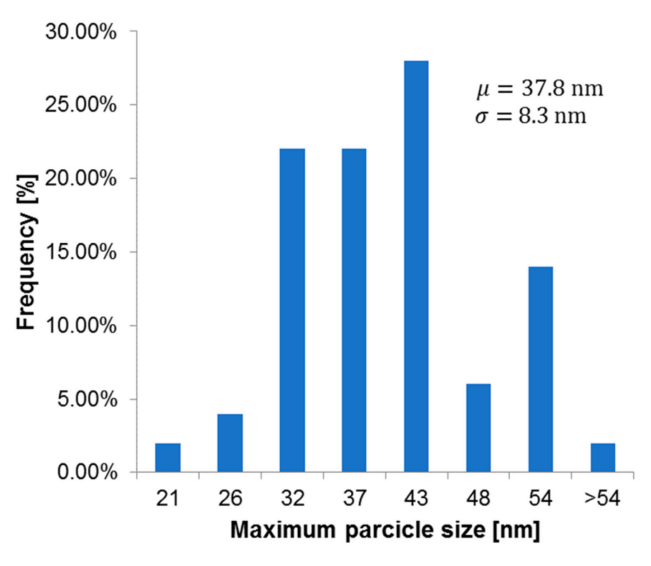

(b)

Figure 4. View of: (a) the transmission electron microscope (TEM) image of $\mathrm{Al}_{2} \mathrm{O}_{3}$ nanopowder particles; (b) the particle size distribution of $\mathrm{Al}_{2} \mathrm{O}_{3}$ nanopowder.

\subsection{The Consistency and Bulk Density of Fresh Mortars}

Figure 5 presents the dependence of Novikow slump test and setting times (Figure 5a), and the bulk density (Figure $5 b$ ) of fresh cement mortars on the content of $\mathrm{Al}_{2} \mathrm{O}_{3}$ nanopowder.

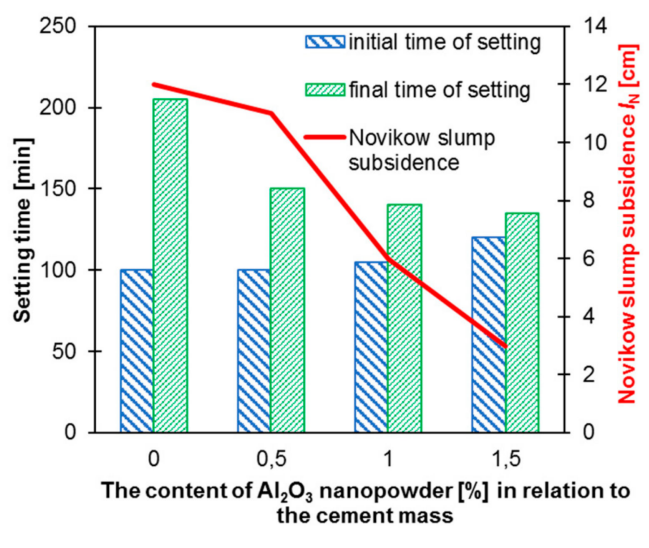

(a)

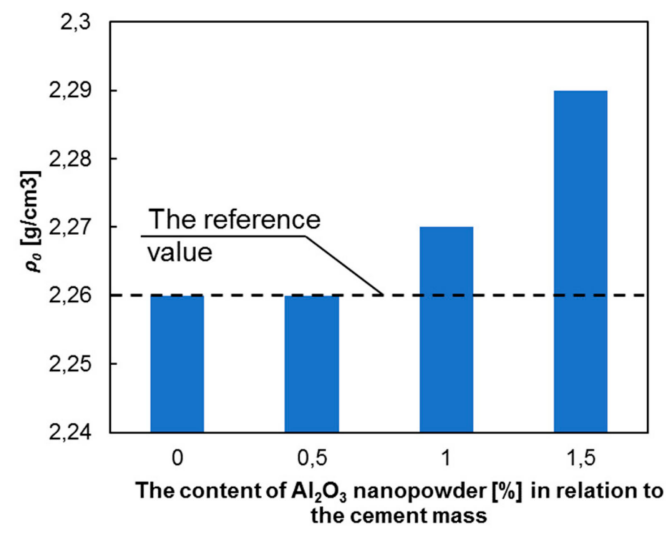

(b)

Figure 5. Test results of fresh cement mortars: (a) Novikow slump test and setting times; (b) bulk density. 
Figure $5 \mathrm{a}$ presents that the final setting time is shortened (maximum by about $34 \%$ ) and the initial time is slightly longer (maximum by about $20 \%$ ) together with the increase of content of $\mathrm{Al}_{2} \mathrm{O}_{3}$ nanopowder in the mortar. The probable reason the decrease of final setting time is faster hydration [76]. It should also be noted that as the content of $\mathrm{Al}_{2} \mathrm{O}_{3}$ nanopowder in the mortar increases, its consistency changes quickly (except for $0.5 \%$ ). For the reference mortar, the Novikow cone dropped to $12 \mathrm{~cm}$. For the addition of $1 \%$ of $\mathrm{Al}_{2} \mathrm{O}_{3}$ nanopowder, it was $6 \mathrm{~cm}$ and for $1.5 \%$ it was $3 \mathrm{~cm}$. It can be seen from Figure $4 \mathrm{~b}$ that the density of the fresh mortar increases with an increasing content of $\mathrm{Al}_{2} \mathrm{O}_{3}$ nanopowder in its composition. However, this increase is not greater than $1.5 \%$.

\subsection{The Mechanical Properties and Porosity of Hardened Cement Mortars}

Figure 6 presents the results of testing the compressive strength, flexural strength and porosity of mortars differing in terms of their percentages of $\mathrm{Al}_{2} \mathrm{O}_{3}$ nanopowder.

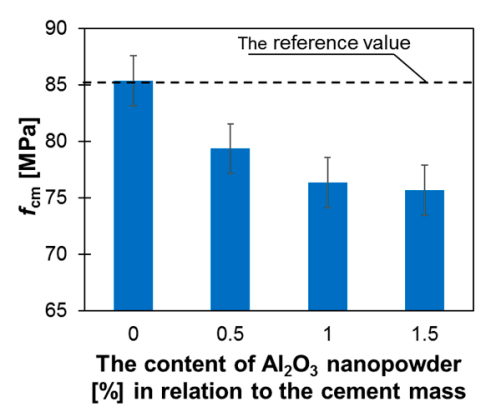

(a)

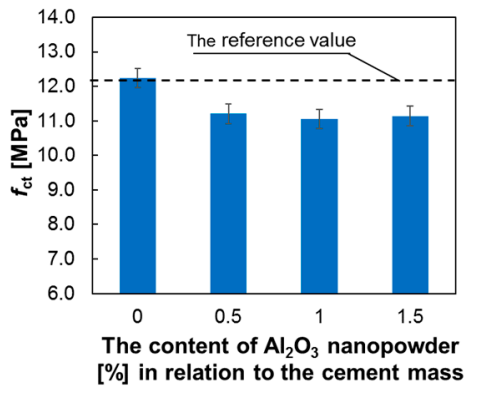

(b)

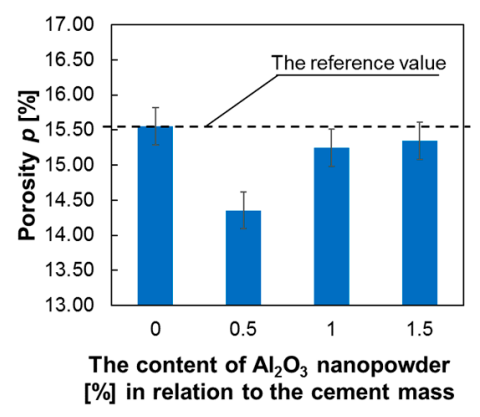

(c)

Figure 6. Test results of mechanical properties and porosity of hardened mortars: (a) compressive strength, (b) flexural strength and (c) porosity.

Figure 5 a presents that the compressive strength of all the tested mortars decreases with increasing amounts of $\mathrm{Al}_{2} \mathrm{O}_{3}$ nanopowder in their composition. For the addition of $0.5 \% \mathrm{Al}_{2} \mathrm{O}_{3}$ nanopowder, this decrease became about $7 \%$; for $1 \%$ it was about $10.6 \%$; and for $1.5 \%$ it was about $11.4 \%$ compared to the reference mortar. In the literature there are papers which report that generally the addition of $\mathrm{Al}_{2} \mathrm{O}_{3}$ nanopowder can increase the compressive strength of mortars [77-79]; however, not at all cases. For example, some results presented, for example, those in papers [80-82], say that although the compressive strength of mortar with addition of $\mathrm{Al}_{2} \mathrm{O}_{3}$ nanopowder increased after three and seven curing days, the compressive strength after 28 days was lower than the value of reference mortar. The flexural strength was also reduced by approximately $10 \%$, regardless of the nanopowder content (Figure $5 \mathrm{~b}$ ). For the addition of $1 \%$ and $1.5 \%$ nanopowder, the porosity is reduced to a maximum of about $2 \%$ in comparison with the reference mortar, and for the addition of $0.5 \%$ of $\mathrm{Al}_{2} \mathrm{O}_{3}$ nanopowder, the decrease of the porosity is about $7.7 \%$. The possible reason for the decrease in mechanical properties could be related to low water/binder ratio of examined mortars (0.3). The addition of $\mathrm{Al}_{2} \mathrm{O}_{3}$ nanopowder decreases water/cement ratio and it can affect development of hydration.

\subsection{The Pull-Off Adhesion of the Cement Mortar Used to Make the Overlay to the Concrete Substrate}

Table 2 presents the test results of the pull-off adhesion $f_{\mathrm{b}}$ of the cement mortar used to make the overlay to the concrete substrate. The results presented in Table 2 confirm the known fact that the application of a bonding agent prior to the application of the cement mortar used to make the overlay increases the pull-off adhesion $f_{\mathrm{b}}$. However, in this case, the mechanical treatment of the concrete substrate surface has a much greater impact on the increase of this adhesion. This is especially noticeable for the shot-blasted surface (increase by approximately $67 \%$ compared to the raw surface R). Such a great increase of adhesion presents how important the way substrate treatments and the morphology of their surface are handled before laying the cement mortar used to make the overlay. In 
paper [17] they referred that in the case of shot-blasted surface, the reason for the increase of adhesion is in increase of the effective surface area and the surface exposure of the coarse aggregate. For the shot-blasted surface $S$, the largest increase in pull-off adhesion $f_{\mathrm{b}}$ was noted for the mortar with the addition of $0.5 \%$ of $\mathrm{Al}_{2} \mathrm{O}_{3}$ nanopowder. Table 2 also presents that the values of the coefficients of variation have a maximum value of about $7.13 \%$ for the raw, shot-blasted and shot-blasted surface with a bonding agent. On the other hand, for the raw surface with bonding agent, these values are several times higher (about $19 \%$ for the reference mortar and a maximum of about $24 \%$ in the mortars with the addition of $\mathrm{Al}_{2} \mathrm{O}_{3}$ nanopowder).

Table 2. Test results of the pull-off adhesion $f_{\mathrm{b}}$ of the cement mortar used to make the overlay to the concrete substrate.

\begin{tabular}{ccccc}
\hline Surface & $\begin{array}{c}\text { Content of } \mathbf{A l}_{\mathbf{2}} \mathbf{O}_{3} \\
\text { Nanopowder }\end{array}$ & Mean Values & $\begin{array}{c}\text { Standard } \\
\text { Deviation }\end{array}$ & $\begin{array}{c}\text { Coefficients of } \\
\text { Variation }\end{array}$ \\
\cline { 2 - 4 } & $\begin{array}{c}\text { (\% of the Mass } \\
\text { of Cement) }\end{array}$ & $\mathbf{( M P a )}$ & $\mathbf{( - )}$ & $\mathbf{( \% )}$ \\
$\mathrm{R}$ & 0 & 1.05 & 0.07 & $6.67 \%$ \\
(Patch grabbed surface) & 0.5 & 1.22 & 0.04 & $3.07 \%$ \\
& 1.0 & 1.24 & 0.04 & $3.29 \%$ \\
R/B & 1.5 & 1.36 & 0.03 & $2.42 \%$ \\
\hline S & 0 & 1.10 & 0.21 & $19.09 \%$ \\
(patch grabbed with & 0.5 & 1.29 & 0.30 & $22.87 \%$ \\
bonding agent) & 1.0 & 1.77 & 0.42 & $23.54 \%$ \\
& 1.5 & 1.56 & 0.30 & $19.38 \%$ \\
\hline S/B & 0 & 1.75 & 0.05 & $2.65 \%$ \\
(shot-blasted surface) & 0.5 & 2.08 & 0.08 & $4.08 \%$ \\
& 1.0 & 1.86 & 0.05 & $2.85 \%$ \\
(shot-blasted surface with & 1.5 & 1.63 & 0.06 & $3.68 \%$ \\
bonding agent) & 0 & 1.97 & 0.09 & $4.62 \%$ \\
& 1.0 & 1.54 & 0.11 & $7.13 \%$ \\
\hline
\end{tabular}

Diversely, Figure 7 presents the relationship between the pull-off adhesion $f_{\mathrm{b}}$ values and the compressive strength $f_{\mathrm{cm}}$ (Figure 7a), flexural strength $f_{\mathrm{ct}}$ (Figure 7b) and porosity $p$ (Figure 7c) for the mortars.

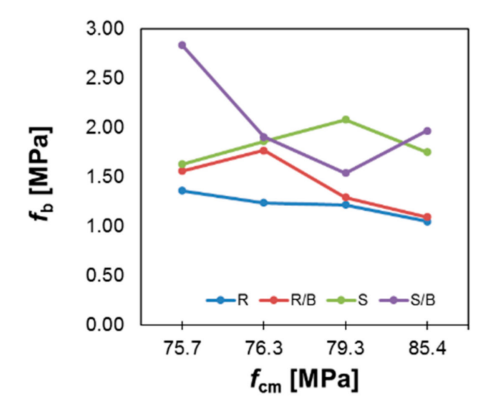

(a)

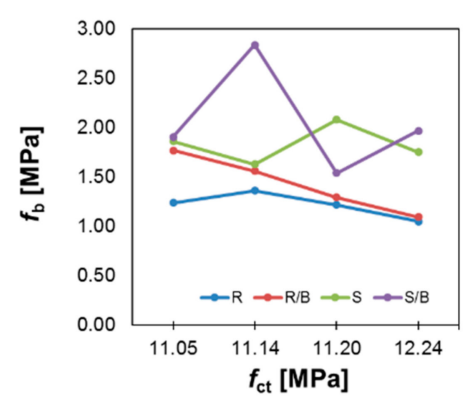

(b)

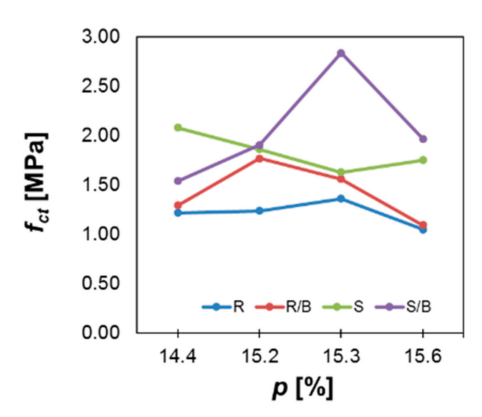

(c)

Figure 7. Relationship between the pull-off adhesion $f_{\mathrm{b}}$ values and the values of: (a) compressive strength $f_{\mathrm{cm}},(\mathbf{b})$ flexural strength $f_{\mathrm{ct}}$ and (c) porosity $p$.

Figure 7 presents that for the raw surface, and the raw surface with the bonding agent; the value of $f_{\mathrm{b}}$ generally decreases as the compressive and flexural strength of the cement mortar used to make the overlay decreases. In this case, there is no clear relationship between porosity and adhesion. It can 
also be seen that the application of the bonding agent before applying the cement mortar used to make the overlay increases the $f_{\mathrm{b}}$ value. For the shot-blasted surface and shot-blasted surface with a bonding agent, the $f_{\mathrm{b}}$ values are higher than for the raw surfaces. In this case, there is no clear relationship between the values of $f_{\mathrm{b}}$ and compressive strength, flexural strength and porosity. However, when considering only the mortars with the addition of $\mathrm{Al}_{2} \mathrm{O}_{3}$ nanopowder, it can be seen that with an increasing compressive strength, the $f_{\mathrm{b}}$ decreases for the shot-blasted surface and for the shot-blasted surface with the bonding agent. It is also visible, that the $f_{\mathrm{b}}$ values decrease with an increasing porosity for the shot-blasted surface and increase for the shot-blasted surface with the bonding agent.

\subsection{The Course of the Longitudinal Velocity of the Ultrasonic Wave along the Thickness of the Cement Mortar Used to Make the Overlay}

Figure 8 presents the course of the longitudinal velocity of the ultrasonic wave $c_{\mathrm{L}}$ along the thickness $H$ of the cement mortar used to make the overlay.

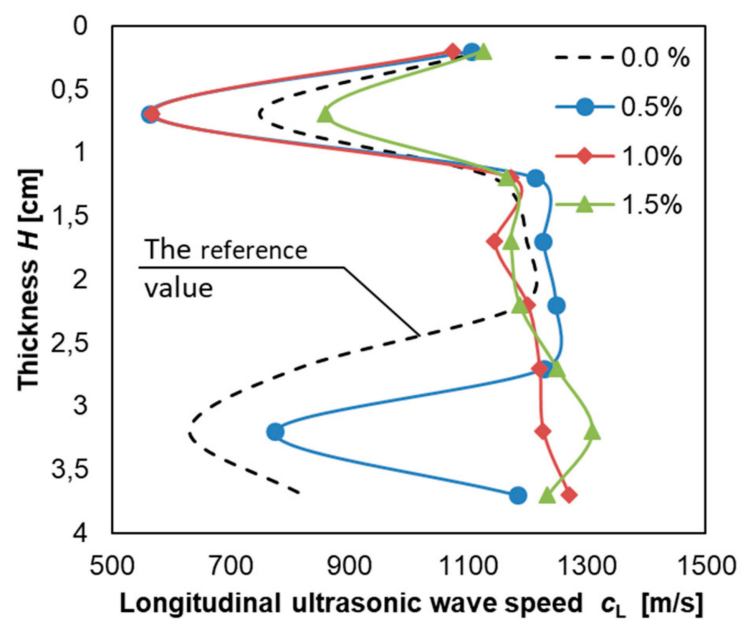

Figure 8. The results of the course of the longitudinal velocity of the ultrasonic wave $c_{\mathrm{L}}$ along the thickness $H$ of the cement mortar used to make the overlay.

It can be concluded from Figure 8, that the values of the longitudinal velocity of the ultrasonic wave $c_{\mathrm{L}}$ for the mortars with the addition of $\mathrm{Al}_{2} \mathrm{O}_{3}$ nanopowder (except mortar with addition of $0.5 \%$ ) differ considerably from the values obtained for the mortar without $\mathrm{Al}_{2} \mathrm{O}_{3}$ nanopowder. That is especially visible in the lower section in Figure 8 (increase of the longitudinal velocity of the ultrasonic wave $c_{\mathrm{L}}$ value by a maximum of about $200 \%$ for the mortars with a $1 \%$ and $1.5 \%$ addition). For the mortar with the addition of $0.5 \%$, the course of ultrasonic velocity is similar but the increase by about $23 \%$ can still be seen. This is especially evident at a thickness of between 3 and $4 \mathrm{~cm}$. In Figure 8 , there are two peaks (in upper zone and bottom zone) which can be caused by patch grabbing the surface of the cement mortar used to make the overlay (the upper zone) and the wall effect [83]. These results are similar to those obtained by Stawiski $[84,85]$, who presented that the quality of the cement mortar in the top zone of an overlay can be much worse than the quality of the cement mortar in the middle and bottom zones. Such great differences in the speed of ultrasonic wave may indicate an increase in the homogeneity of the mortar in the zone close to the interphase zone. Bearing the above in mind, in order to analyze the material microstructure in the interphase zone, samples of the mortar with the addition of $0.5 \%$ of $\mathrm{Al}_{2} \mathrm{O}_{3}$ nanopowder, which was laid on a concrete substrate prepared by shot-blasting, were taken.

\subsection{The Abrasion Resistance of Cement Mortars}

Figure 9 presents the relationship between the abrasion resistance of the mortars tested on the percentage of $\mathrm{Al}_{2} \mathrm{O}_{3}$ nanopowder. 


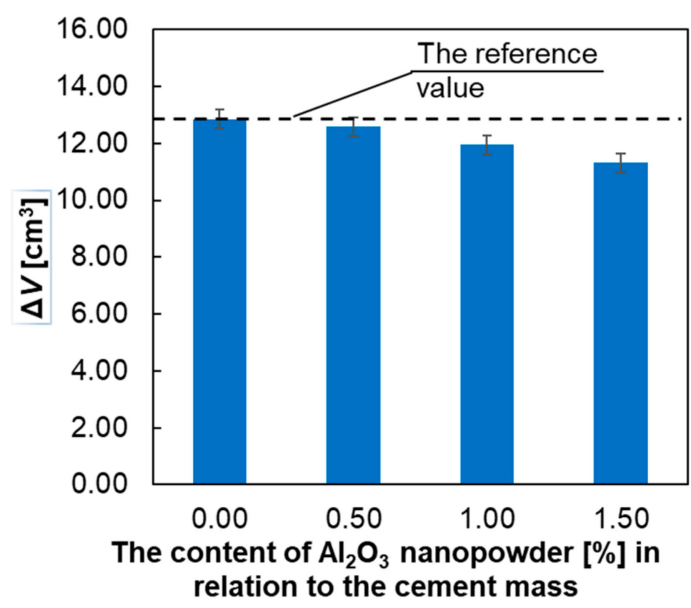

(a)

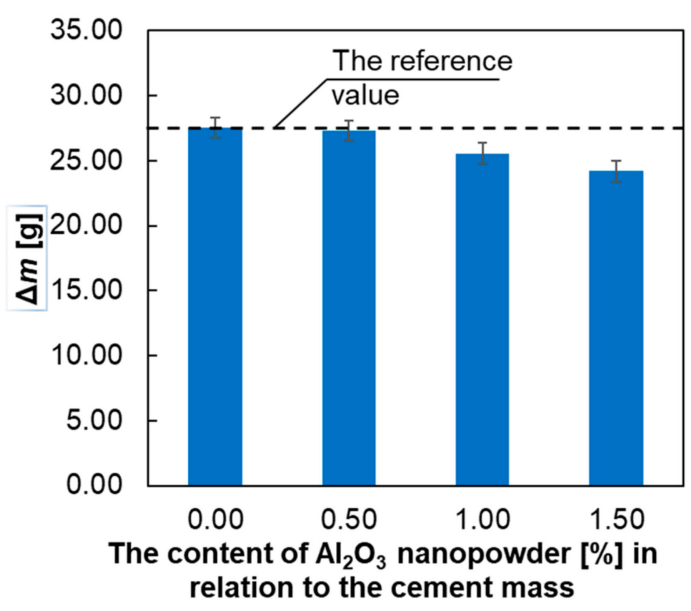

(b)

Figure 9. Test results of the abrasion resistance of the hardened mortars: (a) volume loss $\Delta V ;(\mathbf{b})$ mass loss $\Delta m$.

Figure 9 shows that the abrasion resistance of all the mortars tested with the addition of $\mathrm{Al}_{2} \mathrm{O}_{3}$ nanopowder increased as the percentage of nanopowder increased. The maximum increase in abrasion resistance was observed for the addition of $1.5 \% \mathrm{Al}_{2} \mathrm{O}_{3}$ nanopowder.

\subsection{The Subsurface Tensile Strength and Subsurface Hardness of Cement Mortars}

In turn, Figure 10 presents the dependence of subsurface tensile strength and the subsurface hardness of the cement mortar used to make the overlay, on the percentage of $\mathrm{Al}_{2} \mathrm{O}_{3}$ nanopowder.

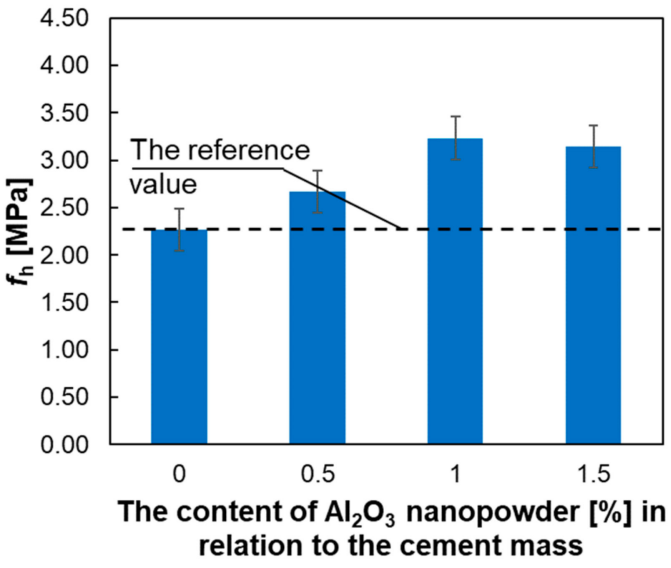

(a)

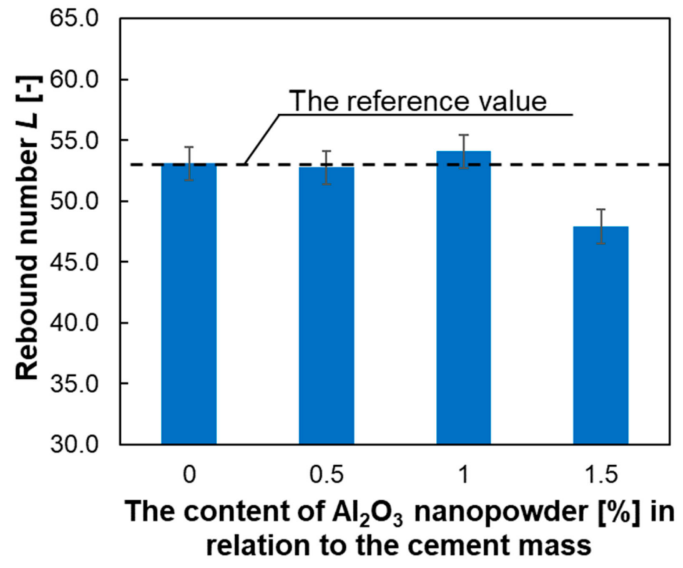

(b)

Figure 10. Test results of the cement mortars: (a) subsurface tensile strength $f_{\mathrm{h}}$; (b) subsurface hardness defined by the rebound number $L$ obtained using the sclerometric method.

Figure 10 shows that the addition of $\mathrm{Al}_{2} \mathrm{O}_{3}$ nanopowder increases the subsurface tensile strength of the cement mortar used to make the overlay. The maximum increase was about $61 \%$ and was observed for the addition of $1 \%$ of $\mathrm{Al}_{2} \mathrm{O}_{3}$ nanopowder. For the $0.5 \%$ of $\mathrm{Al}_{2} \mathrm{O}_{3}$ nanopowder, this increase was about $17 \%$, and for the $1.5 \%$ of $\mathrm{Al}_{2} \mathrm{O}_{3}$ nanopowder it was about $42 \%$. In turn, the hardness of the tested mortars assessed using the sclerometric method does not change significantly, except for the mortar with the addition of $1.5 \%$ of $\mathrm{Al}_{2} \mathrm{O}_{3}$ nanopowder, where the hardness decreased by about $10 \%$. 


\subsection{The Microstructure of the Samples Using a Scanning Electron Microscope (SEM)}

The results of tests using a SEM on the samples taken from the interphase zone are presented below. Gray scale histograms and the BSE images of the samples cut from the interphase zone of the cement mortar used to make the overlay with the concrete substrate made using a SEM are presented in Figure 11. Figure 11a refers to the reference mortar, and Figure $12 \mathrm{~b}$ applies to the mortar with the addition of $0.5 \%$ of $\mathrm{Al}_{2} \mathrm{O}_{3}$ nanopowder. The analyzed areas of the $0.588 \times 0.433 \mathrm{~mm}^{2}$ interphase zone are presented on the left. To analyze the cement matrix itself, the aggregate was cut out from both these images. This procedure was previously used in, e.g., [76]. The histograms presented in Figure 11 present three visible peaks showing pores, hydration products (HP) and anhydrous cement grains $(\mathrm{AH})$, and one smaller peak which corresponds to the calcium hydroxide $(\mathrm{CH})$.

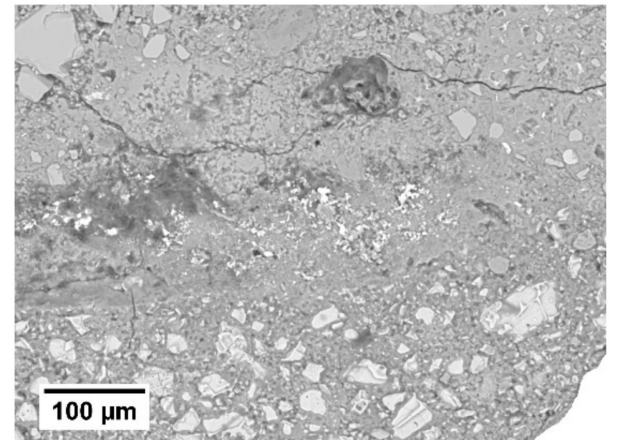

(a)

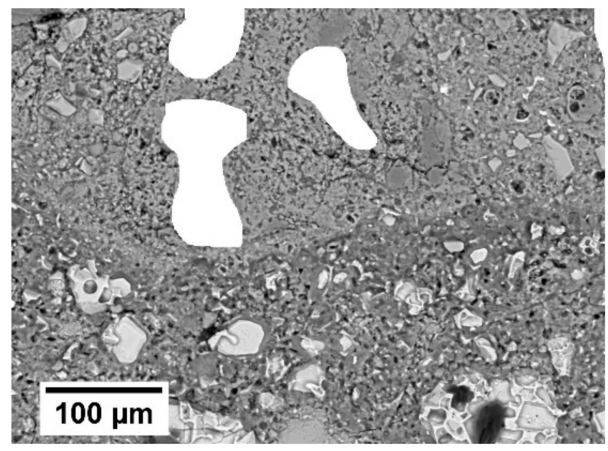

(c)

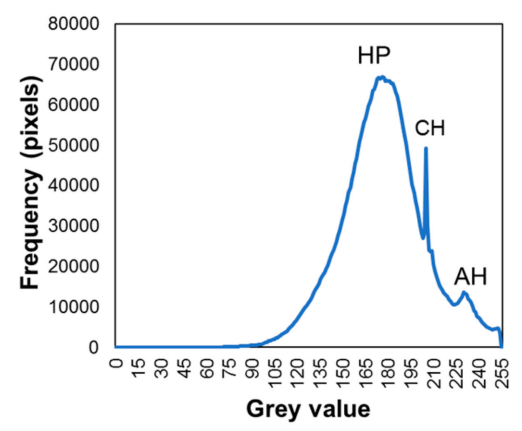

(b)

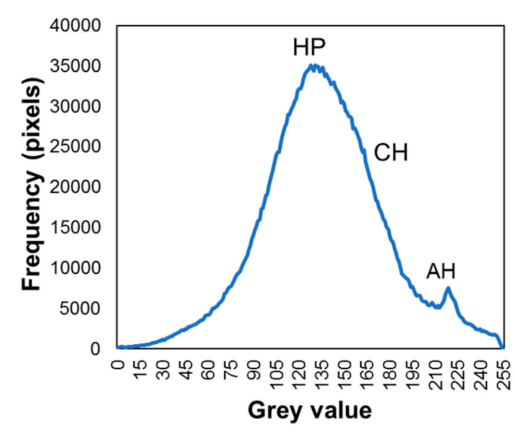

(d)

Figure 11. Exemplary backscattered electron (BSE) images of the samples cut from the interphase zone of the cement mortar used to make the overlay with the concrete substrate $(\mathbf{a}, \mathbf{c})$, which were made using a scanning electron microscope (SEM). Gray scale histograms $(\mathbf{b}, \mathbf{d})$. Figures $(\mathbf{a}, \mathbf{b})$ refer to the reference mortar without $\mathrm{Al}_{2} \mathrm{O}_{3}$ nanopowder and $(\mathbf{c}, \mathbf{d})$ refer to the mortar modified with $0.5 \%$ of $\mathrm{Al}_{2} \mathrm{O}_{3}$ nanopowder.

Alternatively, Figure 12 presents the cumulative gray scale histograms, images of segmented pores and charts of the fractional share of pores along the thickness. Figure 12a refers to the reference mortar, and Figure $12 \mathrm{~b}$ applies to the mortar with the addition of $0.5 \%$ of $\mathrm{Al}_{2} \mathrm{O}_{3}$ nanopowder. The gray scale charts indicate the pore gray scale thresholds with a red arrow (following the procedure described in [76]). These values were used to generate images of the segmented pores, which are presented in the middle of the figure. On the right side of the figure, diagrams displaying the fractional share of pores along the thickness are presented. The red line indicates the center of the interphase. 

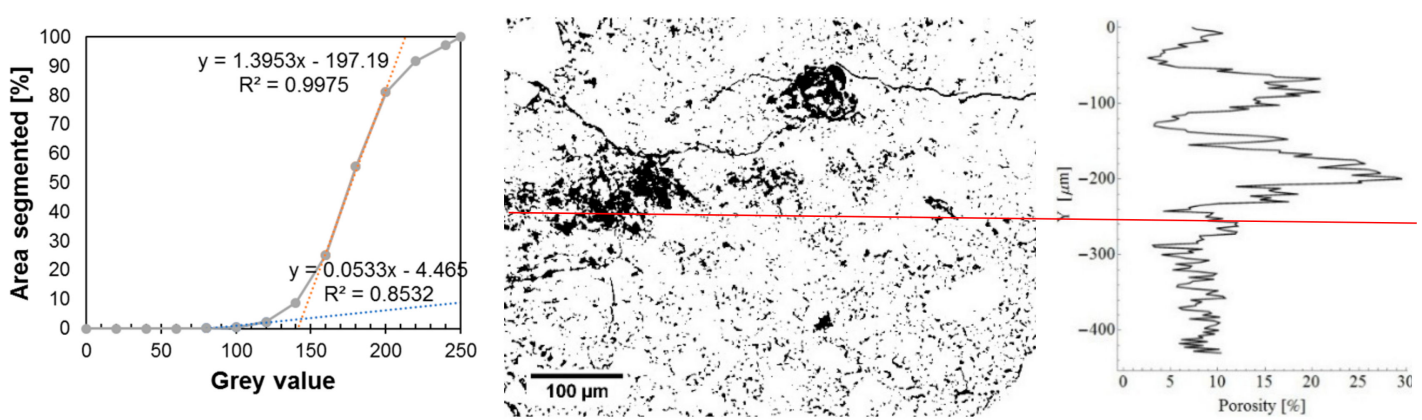

(a)
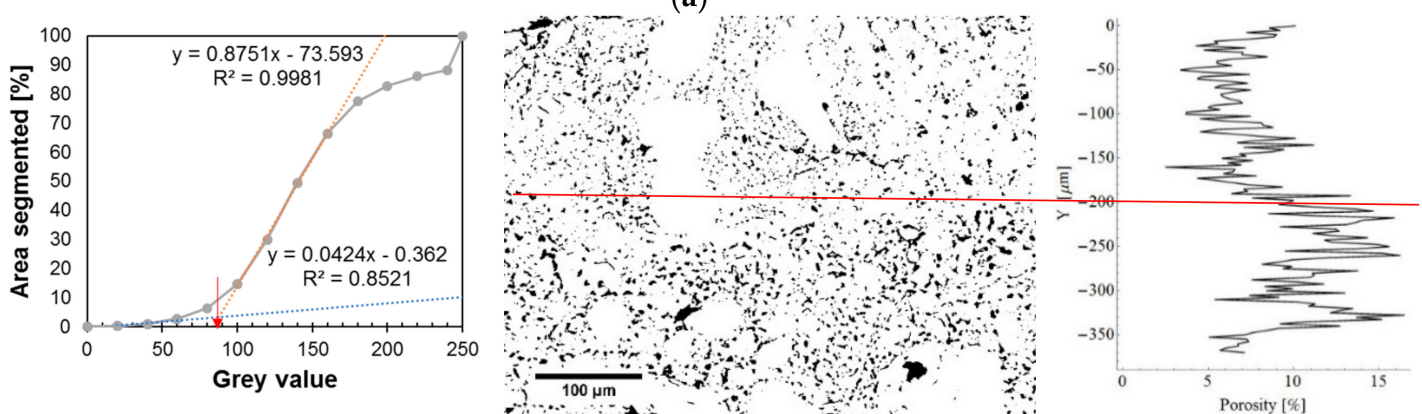

(b)

Figure 12. Exemplary cumulative gray scale histograms, images of segmented pores and charts of the fractional share of pores along the thickness of the interphase zone for the mortar: (a) without $\mathrm{Al}_{2} \mathrm{O}_{3}$ nanopowder; (b) modified with the addition of $0.5 \%$ of $\mathrm{Al}_{2} \mathrm{O}_{3}$ nanopowder.

Figures 11 and 12 show that the mortar with the addition of $0.5 \%$ of $\mathrm{Al}_{2} \mathrm{O}_{3}$ nanopowder has a lower fractional share of pores compared to the reference mortar. The average value of the fractional share of pores for the reference mortar is about $10.18 \%$, and for the mortar with the addition of nanopowder it is $8.38 \%$. The use of $0.5 \%$ of $\mathrm{Al}_{2} \mathrm{O}_{3}$ nanopowder results in a reduction of the fractional share of pores in the interphase zone by about $18 \%$ compared to the reference mortar.

The results of tests using SEM on the samples taken from the subsurface zone of the cement mortar used to make the overlay are presented below. Figure 13 presents electron microscope (BSE) images and gray scale histograms.

The gray scale histogram for the reference mortar (Figure 13a) presents three large peaks and one much smaller peak. Large peaks are related to the pores, hydration products (HP) and anhydrous cement grains $(\mathrm{AH})$, and a much smaller peak is related to the calcium hydroxide $(\mathrm{CH})$. In turn, on the histogram presented in Figure 13b, the peak related to the pores is not clearly visible for the mortar with $0.5 \%$ of $\mathrm{Al}_{2} \mathrm{O}_{3}$ nanopowder. Figure 13 shows that the subsurface zone of the mortar with $0.5 \%$ of $\mathrm{Al}_{2} \mathrm{O}_{3}$ nanopowder is less porous compared to the reference mortar.

As a result of binarization, Figure 14 presents the cumulative gray scale histograms, images of segmented pores and charts of the fractional share of pores extracted from the BSE images presented in Figure 13. Figure 14 refers to the subsurface zone of the reference mortar used to make the overlay (Figure 14a) and for the mortar with $0.5 \%$ of $\mathrm{Al}_{2} \mathrm{O}_{3}$ nanopowder (Figure $14 \mathrm{~b}$ ). On the cumulative gray scale histograms, the pore gray scale threshold is marked with a red arrow (following the procedure presented in [76]). Then, the fractional fraction of pores was determined for the reference mortar $(18.54 \%)$ and for the mortar with the addition of $0.5 \%$ of $\mathrm{Al}_{2} \mathrm{O}_{3}$ nanopowder $(11.16 \%)$. 

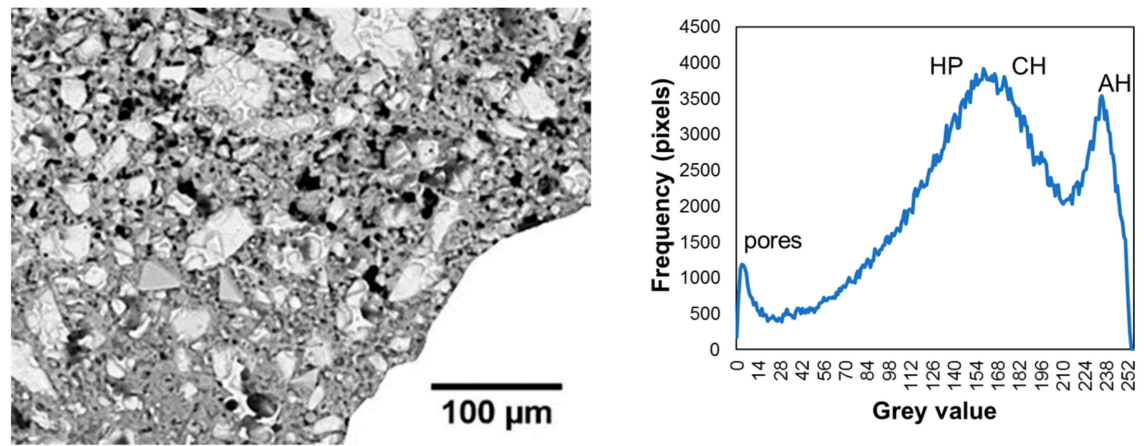

(a)
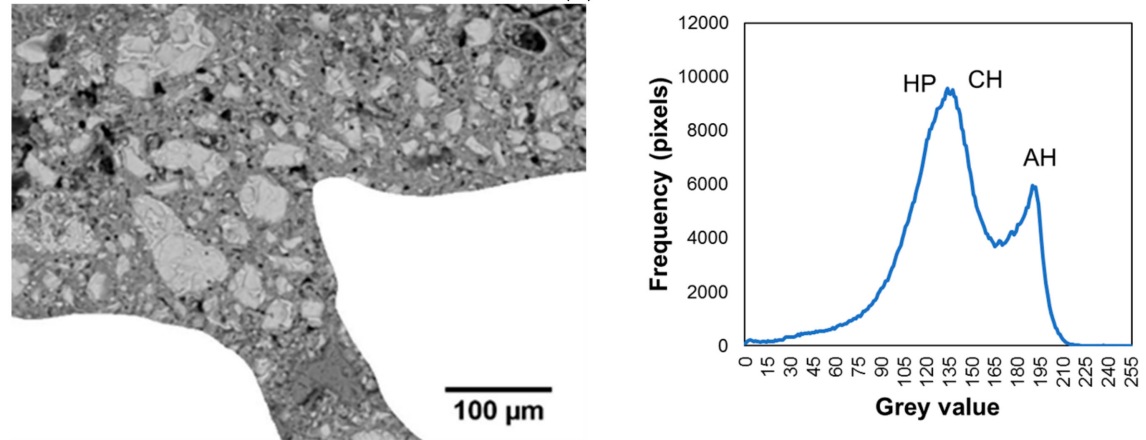

(b)

Figure 13. Exemplary backscattered electron (BSE) images of the samples taken from the subsurface zone of the cement mortar used to make the overlay with the concrete substrate, which were made using scanning electron microscope (SEM); and gray scale histograms for the mortar: (a) without $\mathrm{Al}_{2} \mathrm{O}_{3}$ nanopowder; (b) modified with the addition of $0.5 \% \mathrm{Al}_{2} \mathrm{O}_{3}$ nanopowder.
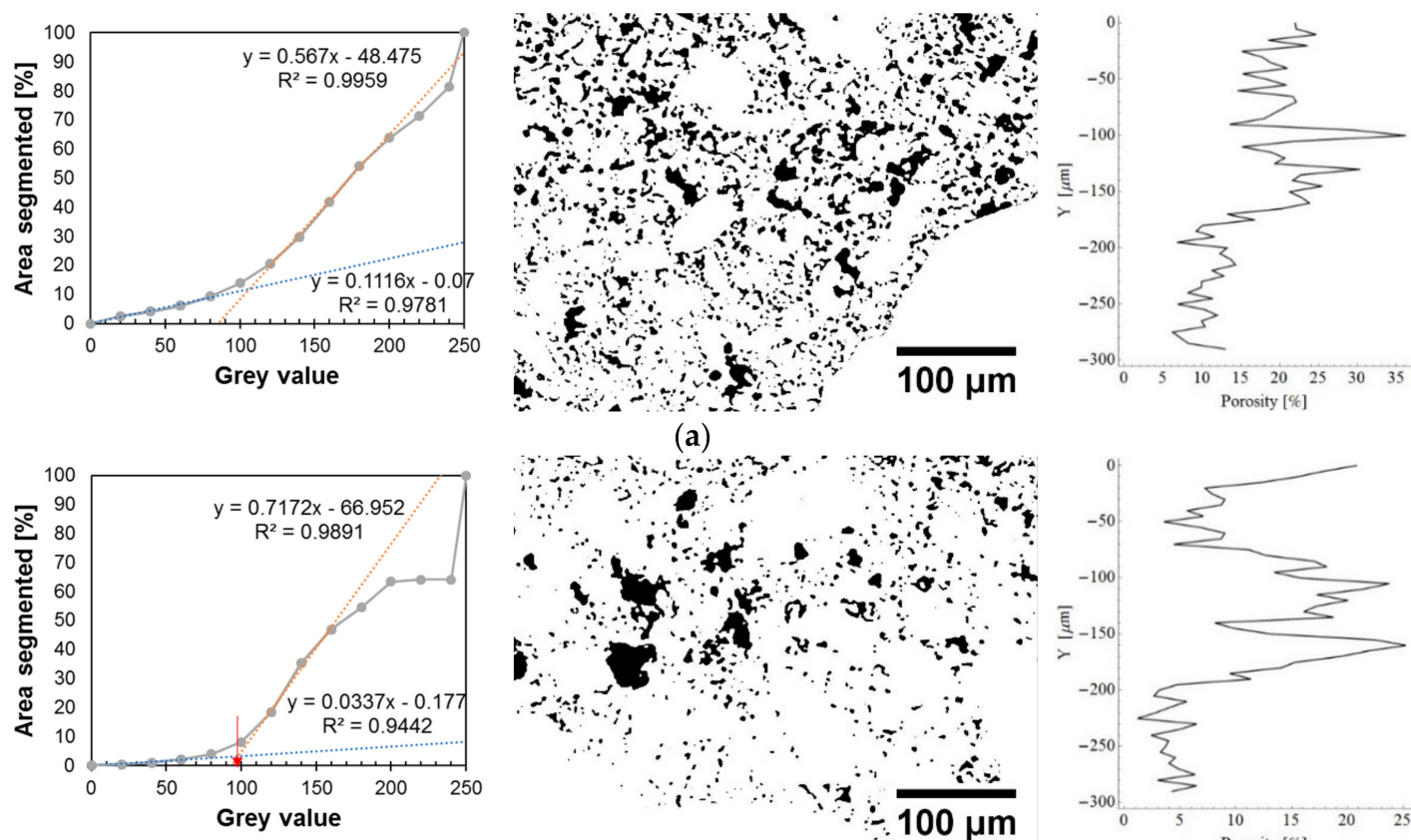

(a)

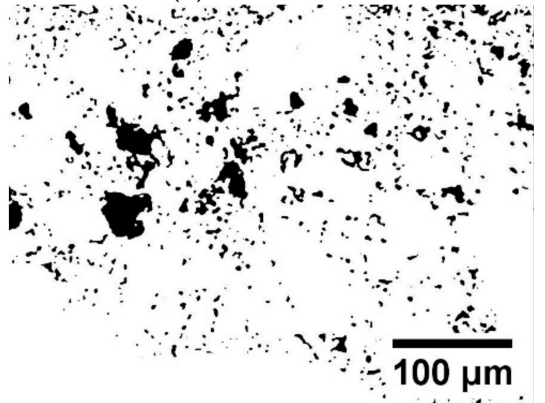

(b)

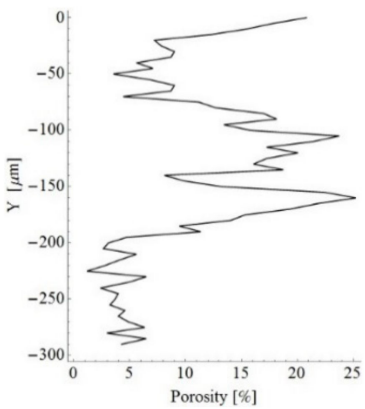

Figure 14. Exemplary cumulative gray scale histograms, images of segmented pores and charts of the fractional share of pores along the thickness within the subsurface zone for the mortar: (a) without $\mathrm{Al}_{2} \mathrm{O}_{3}$ nanopowder; (b) modified with the addition of $0.5 \%$ of $\mathrm{Al}_{2} \mathrm{O}_{3}$ nanopowder. 
Figure 14 shows that the mortar with $0.5 \%$ of $\mathrm{Al}_{2} \mathrm{O}_{3}$ nanopowder has a smaller fractional share of pores at a thickness of $200 \mu \mathrm{m}$ from the surface of the cement mortar used to make the overlay. The value of this fractional share of pores is about $15 \%$, and for the reference mortar the value is about $20 \%$. At a depth of less than $200 \mu \mathrm{m}$, the value of the fractional share of pores for both mortars decreases and is about $5 \%$ for the mortar with the addition of $0.5 \%$ of $\mathrm{Al}_{2} \mathrm{O}_{3}$ nanopowder and about $10 \%$ for the reference mortar.

Figure 15 presents the fractional share of pores in the range of $0.83-25 \mu \mathrm{m} / \mathrm{mm}^{2}$ in the reference mortar and in the mortar with $0.5 \%$ of $\mathrm{Al}_{2} \mathrm{O}_{3}$ nanopowder.

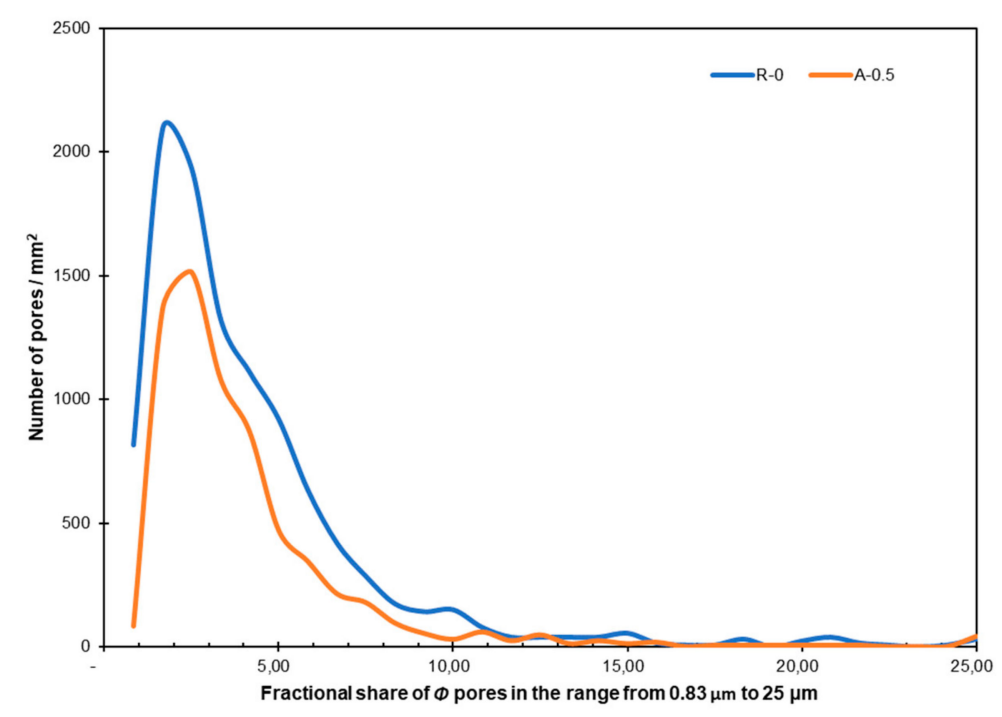

Figure 15. The fractional share of pores in the range of $0.83-25 \mu \mathrm{m} / \mathrm{mm}^{2}$ in the reference mortar and in the mortar with $0.5 \%$ of $\mathrm{Al}_{2} \mathrm{O}_{3}$ nanopowder.

Figure 15 shows that the matrix with $0.5 \%$ of $\mathrm{Al}_{2} \mathrm{O}_{3}$ nanopowder is less porous compared to the reference mortar. That is visible, especially for pores with sizes in the range of $0.83-10 \mu \mathrm{m}$. In both analyzed matrices, the largest number of pores was in the range of 2 to $3 \mu \mathrm{m}$ (about 2100 pores per $1 \mathrm{~mm}^{2}$ in the reference mortar and about 1500 pores per $1 \mathrm{~mm}^{2}$ in the case of the mortar with the addition of $0.5 \%$ of $\mathrm{Al}_{2} \mathrm{O}_{3}$ nanopowder). The total fractional share of pores in the matrix was about $18.5 \%$ for the reference mortar and about $11.2 \%$ for the mortar with the addition of $0.5 \%$ of $\mathrm{Al}_{2} \mathrm{O}_{3}$ nanopowder.

\section{Conclusions}

The article focuses on the effect of applying aluminum oxide $\left(\mathrm{Al}_{2} \mathrm{O}_{3}\right)$ nanopowder to cement mortar used to make the overlay, on the adhesion of this overlay to concrete substrate, and also its effect on the functional properties of the cement mortar used to make the overlay. The following conclusions cane be drawn:

1. The studies conducted of setting times, tests using the Novikow cone and tests of the bulk density of the fresh cement mortars showed that, with an increasing content of $\mathrm{Al}_{2} \mathrm{O}_{3}$ nanopowder in the cement mortar, the consistency of the mixture deteriorates. The exception is the addition of $0.5 \%$ of $\mathrm{Al}_{2} \mathrm{O}_{3}$ nanopowder, for which the consistency of the mix is at a lower level when compared to the mortar without nanopowder in its composition. In addition, the increase in content of $\mathrm{Al}_{2} \mathrm{O}_{3}$ nanopowder, compared to the reference mortar, causes the shortening of the initial setting time and extending of the final setting time. It was found that the bulk density of fresh mortar is higher, together with an increase of the content of $\mathrm{Al}_{2} \mathrm{O}_{3}$ nanopowder. However, this was not the case for the addition of $0.5 \%$, for which the density is at the same level in relation to the reference mortar. 
2. It was found that the mechanical properties and porosity of the hardened mortar do not depend on the addition of $\mathrm{Al}_{2} \mathrm{O}_{3}$ nanopowder. Only the addition of $0.5 \%$ of $\mathrm{Al}_{2} \mathrm{O}_{3}$ nanopowder decreases the porosity in comparison to the reference mortar without nanopowder in its composition. In turn, the addition of $0.5 \%, 1.0 \%$ and $1.5 \%$ of $\mathrm{Al}_{2} \mathrm{O}_{3}$ nanopowder results in a lower compressive and flexural strengths than for the reference mortar.

3. The results obtained using the pull-off method show that the addition of $0.5 \%$ of $\mathrm{Al}_{2} \mathrm{O}_{3}$ nanopowder has a positive effect on the pull-off adhesion $f_{\mathrm{b}}$ of the cement mortar used to make the overlay to the concrete substrate. It was shown that the addition of $\mathrm{Al}_{2} \mathrm{O}_{3}$ nanopowder considerably reduces the coefficient of variation and standard deviation of the values obtained of the pull-off adhesion $f_{\mathrm{b}}$. This was confirmed by ultrasonic tests, which presented that the addition of $\mathrm{Al}_{2} \mathrm{O}_{3}$ nanopowder in cement mortar has a very positive effect on the longitudinal wave speed $c_{\mathrm{L}}$ at a distance of about $15 \mathrm{~mm}$ from the interphase between the cement mortar used to make the overlay and the concrete substrate. This was also confirmed by the research carried out using a scanning electron microscope (SEM), which proved that the reason for improving the adhesion is the fact that the mortar with $0.5 \%$ of $\mathrm{Al}_{2} \mathrm{O}_{3}$ nanopowder is less porous compared to the reference mortar.

4. The results of the abrasion resistance tests were that when using $1.0 \%$ and $1.5 \%$ of $\mathrm{Al}_{2} \mathrm{O}_{3}$ nanopowder, the abrasion resistance of the cement mortar used to make the overlay increased in comparison with the reference mortar. It was also found that the mortar made with $0.5 \%$, $1.0 \%$ and $1.5 \%$ of $\mathrm{Al}_{2} \mathrm{O}_{3}$ nanopowder had a lower subsurface tensile strength in relation to the reference mortar. On the other hand, the subsurface hardness of the cement mortar used to make the overlay, detected using the sclerometric method, does not depend on the addition of $\mathrm{Al}_{2} \mathrm{O}_{3}$ nanopowder. The most favorable results, in terms of lower abrasion resistance and higher subsurface tensile strength, are mainly brought about by the use of $0.5 \%$ of $\mathrm{Al}_{2} \mathrm{O}_{3}$ nanopowder. The studies performed using SEM confirmed that the reason for the improvement in abrasion resistance and subsurface tensile strength is the fact that the mortar with the addition of $0.5 \%$ of $\mathrm{Al}_{2} \mathrm{O}_{3}$ nanopowder is less porous than the reference mortar.

Author Contributions: Conceptualization, J.S.; Methodology, J.S.; Investigation, J.S.; Writing—original draft preparation, J.S.; Writing—review and editing, J.S. and Ł.S.; Supervision, Ł.S.

Funding: This research received no external funding.

Conflicts of Interest: The authors declare no conflict of interest.

\section{References}

1. Czarnecki, L.; Emmons, P.H. Repair and Protection of Concrete Structures; CRC Press: Boca Raton, FL, USA, 2002.

2. Król, M. Naprawy i wzmocnienia konstrukcji budowlanych. Przegląd Bud. 2009, 80, 30-36.

3. Ściślewski, Z. Ochrona konstrukcji żelbetowych; Arkady: Warszawa, Poland, 1999.

4. Raupach, M.; Büttner, T. Concrete Repair to EN 1504: Diagnosis, Design, Principles and Practice; CRC Press: Boca Raton, FL, USA, 2014.

5. Czarnecki, L.; Łukowski, P.; Garbacz, A. Naprawa i Ochrona Konstrukcji z Betonu-Komentarz do PN-EN 1504; Wydawnictwo Naukowe PWN: Warszawa, Poland, 2017.

6. Kosior-Kazberuk, M. Metody doboru materiałów do ochrony i napraw konstrukcji żelbetowych zgodnie z EN 1504. Zeszyty Naukowe Politechniki Biatostockiej. Budownictwo 2007, 31, 151-161.

7. Raupach, M. Concrete repair according to the new European standard EN 1504. In Concrete Repair, Rehabilitation and Retrofitting; Taylor \& Francis: London, UK, 2006; pp. 6-8.

8. Lukovic, M.; Ye, G.; Van Breugel, K. Reliable concrete repair: A critical review. In Proceedings of the 14th International Conference Structural Faults and Repair, Edinburgh, UK, 3-5 July 2012.

9. Lukovic, M.; Ye, G. Effect of moisture exchange on interface formation in the repair system studied by X-ray absorption. Materials 2016, 91, 2. [CrossRef] [PubMed]

10. Sadowski, Ł.; Mathia, T.G. Multi-scale metrology of concrete surface morphology: Fundamentals and specificity. Constr. Build. Mater. 2016, 113, 613-621. [CrossRef] 
11. Luković, M.; Ye, G.; Schlangen, E.; van Breugel, K. Moisture movement in cement-based repair systems monitored by X-ray absorption. Heron 2017, 621, 21.

12. Luković, M.; Šavija, B.; Schlangen, E.; Ye, G.; van Breugel, K. A 3D lattice modelling study of drying shrinkage damage in concrete repair systems. Materials 2016, 97, 575. [CrossRef]

13. Lukovic, M.; Schlangen, E.; Ye, G.; Savija, B. Impact of surface roughness on the debonding mechanism in concrete repairs. In Proceedings of the 8th International Conference on Fracture Mechanics of Concrete and Concrete Structures, Toledo, Spain, 10-14 March 2013.

14. Garbacz, A.; Górka, M.; Courard, L. Effect of concrete surface treatment on adhesion in repair systems. Mag. Concr. Res. 2005, 571, 49-60. [CrossRef]

15. Van Der Putten, J.; De Schutter, G.; Van Tittelboom, K. Surface modification as a technique to improve inter-layer bonding strength in 3D printed cementitious materials. Rilem Tech. Lett. 2019, 4, 33-38. [CrossRef]

16. Balakrishnan, V.S.; Obrosov, A.; Kuke, F.; Seidlitz, H.; Weiß, S. Influence of metal surface preparation on the flexural strength and impact damage behaviour of thermoplastic FRP reinforced metal laminate made by press forming. Compos. Part B Eng. 2019, 173, 106883. [CrossRef]

17. Sadowski, Ł.; Żak, A.; Hoła, J. Multi-sensor evaluation of the concrete within the interlayer bond with regard to pull-off adhesion. Arch. Civ. Mech. Eng. 2018, 18, 573-582. [CrossRef]

18. Sadowski, Ł.; Krzywiński, K.; Michoń, M. The influence of texturing of the surface of concrete substrate on its adhesion to cement mortar overlay. J. Adhes. Accept. 2019, 1-14. [CrossRef]

19. Krzywiński, K.; Sadowski, Ł. The effect of texturing of the surface of concrete substrate on the pull-off strength of epoxy resin coating. Coatings 2019, 92, 143. [CrossRef]

20. Santos, D.S.; Santos, P.M.D.; Dias-da-Costa, D. Effect of surface preparation and bonding agent on the concrete-to-concrete interface strength. Constr. Build. Mater. 2012, 37, 102-110. [CrossRef]

21. Xiong, G.; Luo, B.; Wu, X.; Li, G.; Chen, L. Influence of silane coupling agent on quality of interfacial transition zone between concrete substrate and repair materials. Cem. Concr. Compos. 2006, 28, 97-101. [CrossRef]

22. Błaszczyński, T.; Jasiczak, J.; Ksit, B.; Siewczyńska, M. Aspects of bond layer role in concrete repairs. Arch. Civ. Mech. Eng. 2006, 6, 75-87. [CrossRef]

23. Mohammadi, M.; Moghtadaei, R.M.; Ashraf Samani, N. Influence of silica fume and metakaolin with two different types of interfacial adhesives on the bond strength of repaired concrete. Constr. Build. Mater. 2014, 51, 141-150. [CrossRef]

24. Kuo, W.T.; Liu, M.Y.; Juang, C.U. Bonding Behavior of Repair Material Using Fly-Ash/Ground Granulated Blast Furnace Slag-Based Geopolymer. Materials 2019, 1210, 1697. [CrossRef]

25. Gomaa, E.; Gheni, A.A.; Kashosi, C.; ElGawady, M.A. Bond strength of eco-friendly class C fly ash based alkali-activated concrete to portland cement concrete. J. Clean. Prod. 2019, 235, 404-416. [CrossRef]

26. Sabah, S.A.; Hassan, M.H.; Bunnori, N.M.; Johari, M.M. Bond strength of the interface between normal concrete substrate and GUSMRC repair material overlay. Constr. Build. Mater. 2019, 216, 261-271. [CrossRef]

27. Zanotti, C.; Borges, P.H.; Bhutta, A.; Banthia, N. Bond strength between concrete substrate and metakaolin geopolymer repair mortar: Effect of curing regime and PVA fiber reinforcement. Cem. Concr. Compos. 2017, 80, 307-316. [CrossRef]

28. Nunes, V.A.; Borges, P.H.; Zanotti, C. Mechanical compatibility and adhesion between alkali-activated repair mortars and Portland cement concrete substrate. Constr. Build. Mater. 2019, 215, 569-581. [CrossRef]

29. El-Rakib, T.M.; Farahat, A.M.; El-Degwy, W.M.; Shaheen, H.H. Shear transfer parameters at the interface between old and new concrete. In Proceedings of the International Conference on Performance of Construction Materials in the New Millennium (ICPCM), Elmaarefa Printing House, Cairo, Egypt, 18-20 February 2003.

30. Robayo-Salazar, R.; Jesús, C.; de Gutiérrez, R.M.; Pacheco-Torgal, F. Alkali-activated binary mortar based on natural volcanic pozzolan for repair applications. J. Build. Eng. 2019, 25, 100785. [CrossRef]

31. Qin, J.; Qian, J.; You, C.; Fan, Y.; Li, Z.; Wang, H. Bond behavior and interfacial micro-characteristics of magnesium phosphate cement onto old concrete substrate. Constr. Build. Mater. 2018, 167, 166-176. [CrossRef]

32. Sadowski, Ł.; Hoła, J. Wpływ wybranych kwarcowych dodatków mineralnych modyfikujacych beton warstwy wierzchniej na jego zespolenie z podkładem betonowym. Bud. O Zoptymalizowanym Potencjale Energetycznym 2017, 119, 21-26. [CrossRef]

33. Luković, M.; Šavija, B.; Dong, H.; Schlangen, E.; Ye, G. Micromechanical study of the interface properties in concrete repair systems. J. Adv. Concr. Technol. 2014, 129, 320-339. [CrossRef] 
34. Binici, H. Effect of crushed ceramic and basaltic pumice as fine aggregates on concrete mortars properties. Constr. Build. Mater. 2007, 216, 1191-1197. [CrossRef]

35. Barnat-Hunek, D.; Łagód, G.; Fic, S.; Jarosz-Hadam, M. Effect of Polysiloxanes on Roughness and Durability of Basalt Fibres-Reinforced Cement Mortar. Polymers 2018, 104, 420. [CrossRef]

36. Halicka, A.; Ogrodnik, P.; Zegardlo, B. Using ceramic sanitary ware waste as concrete aggregate. Constr. Build. Mater. 2013, 48, 295-305. [CrossRef]

37. Felekoğlu, B.; Türkel, S.; Altuntaş, Y. Effects of steel fiber reinforcement on surface wear resistance of self-compacting repair mortars. Cem. Concr. Compos. 2007, 295, 391-396. [CrossRef]

38. Giergiczny, Z. Dodatki mineralne-niezastapione składniki współczesnego cementu i betonu. Mater. Bud. 2009, 3, 46-50.

39. Golewski, G.L. A novel specific requirements for materials used in reinforced concrete composites subjected to dynamic loads. Compos. Struct. 2019, 223, 110939. [CrossRef]

40. Golewski, G.L. An assessment of microcracks in the Interfacial Transition Zone of durable concrete composites with fly ash additives. Compos. Struct. 2018, 200, 515-520. [CrossRef]

41. Kurdowski, W. Dodatki mineralne do cementu a trwałość betonu. Monografia 1991, 106, 109-120.

42. Łukowski, P. Modyfikacja materiałowa betonu; Stowarzyszenie Producentów Cementu: Kraków, Poland, 2016.

43. Karunarathne, V.K.; Paul, S.C.; Šavija, B. Development of Nano-SiO2 and Bentonite-Based Mortars for Corrosion Protection of Reinforcing Steel. Materials 2019, 1216, 2622. [CrossRef] [PubMed]

44. Cai, Y.; Xuan, D.; Poon, C.S. Effects of nano-SiO2 and glass powder on mitigating alkali-silica reaction of cement glass mortars. Constr. Build. Mater. 2019, 201, 295-302. [CrossRef]

45. Szymanowski, J. Evaluation of the adhesion between overlays and substrates in concrete floors: Literature survey, recent non-destructive and semi-destructive testing methods and research gaps. Buildings 2019, 9, 203. [CrossRef]

46. Sanchez, F.; Sobolev, K. Nanotechnology in concrete-A review. Constr. Build. Mater. 2010, 24, $2060-2071$. [CrossRef]

47. Sikora, P.; Abd Elrahman, M.; Stephan, D. The Influence of nanomaterials on the thermal resistance of cement-based composites-A Review. Nanomaterials 2018, 87, 465. [CrossRef]

48. Horszczaruk, E. Properties of cement-based composites modified with magnetite nanoparticles: A review. Materials 2019, 122, 326. [CrossRef]

49. Czarnecki, L. Czy nanotechnologia to przyszłość betonu? Mater. Bud. 2007, 11, 4-5.

50. Shah, S.P.; Hou, P.; Konsta-Gdoutos, M.S. Nano-modification of cementitious material: Toward a stronger and durable concrete. J. Sustain. Cem. Based Mater. 2016, 5, 1-22. [CrossRef]

51. Yang, X.; Sun, L.; Huang, B.; Zhan, B.; Zhang, C.; Chu, Y.; An, D. Tuning the properties of functional adhesives with hybrid nanofillers for structural health monitoring. J. Adhes. 2019, 1-16. [CrossRef]

52. Niewiadomski, P. Short overview of the effects of nanoparticles on mechanical properties of concrete. In Key Engineering Materials; Trans Tech Publications: Baech, Switzerland, 2015; Volume 662, pp. 257-260.

53. Iskra-Kozak, W.; Konkol, J. Concrete nanomodification with selected nanoparticles. Czas. Inżynierii LadowejŚrodowiska I Archit. 2018, 65, 113-120. [CrossRef]

54. Szymanowski, J.; Sadowski, Ł. Functional and adhesive properties of cement-based overlays modifies with amorphous silica nanospheres. J. Adhes. 2019, 1-22. [CrossRef]

55. Stefaniuk, D.; Niewiadomski, P.; Musiał, M.; Łydżba, D. Elastic properties of self-compacting concrete modified with nanoparticles: Multiscale approach. Arch. Civ. Mech. Eng. 2019, 194, 1150-1162. [CrossRef]

56. Chen, J.; Liang, C.; Li, B.; Wang, E.; Li, G.; Hou, X. The effect of nano- $\gamma$ Al2O3 additive on early hydration of calcium aluminate cement. Constr. Build. Mater. 2018, 158, 755-760. [CrossRef]

57. Zhai, L.L.; Ling, G.P.; Wang, Y.W. Effect of nano- $\mathrm{Al}_{2} \mathrm{O}_{3}$ on adhesion strength of epoxy adhesive and steel. Int. J. Adhes. Adhes. 2008, 28, 23-28. [CrossRef]

58. Phoo-ngernkham, T.; Chindaprasirt, P.; Sata, V.; Hanjitsuwan, S.; Hatanaka, S. The effect of adding nano-SiO2 and nano-Al2O3 on properties of high calcium fly ash geopolymer cured at ambient temperature. Mater. Des. 2014, 55, 58-65. [CrossRef]

59. Silva, J.V.; Ismael, R.; Carmo, R.N.F.; Lourenço, C.; Soldado, E.; Costa, H.; Júlio, E. Influence of nano-SiO2 and nano-Al2O3 additions on the shear strength and the bending moment capacity of RC beams. Constr. Build. Mater. 2016, 123, 35-46. [CrossRef] 
60. Gupta, S.K.; Shukla, D.K.; Kaustubh Ravindra, D. Effect of nanoalumina in epoxy adhesive on lap shear strength and fracture toughness of aluminium joints. J. Adhes. 2019, 1-23. [CrossRef]

61. PN-B-04500:1985. Zaprawy budowlane-Badania cech fizycznych i wytrzymałościowych. Available online: http://sklep.pkn.pl/pn-b-04500-1985p.html (accessed on 16 March 2019).

62. EN 1015-6:2000. Metody badań zapraw do murów-Określenie gęstości objętościowej świeżej zaprawy. Available online: http://sklep.pkn.pl/pn-en-1015-6-2000p.html (accessed on 16 March 2019).

63. EN 196-1: 2016. Methods of testing cement-Part 1: Determination of compressive strength. Available online: http://sklep.pkn.pl/pn-en-196-1-2016-07p.html (accessed on 16 March 2019).

64. EN 13892-2: 2004. Methods of test for screed materials-Part 2: Determination of flexural and compressive strength. Available online: http://sklep.pkn.pl/pn-en-13892-2-2004p.html (accessed on 16 March 2019).

65. EN, B. 1542_-Products and Systems for the Protection and Repair of Concrete Structures-Test Methods-Measurement of Bond Strength by Pull-Off; British Standard Institution: London, UK, 1999.

66. Gudra, T.; Stawiski, B. Non-destructive strength characterization of concrete using surface waves. Ndt E Int. 2000, 33, 1-6. [CrossRef]

67. Ongpeng, J.M.; Oreta, A.W.; Hirose, S. Characterization of Damage Using Ultrasonic Testing on Different Types of Concrete. Mater. Eval. 2018, 7611, 1532-1541.

68. Czarnecki, S. Ultrasonic Evaluation of the pull-off adhesion between added repair layer and a concrete substrate. In IOP Conference Series: Materials Science and Engineering; IOP: London, UK, 2007; Volume 245, p. 032037.

69. Szymanowski, J.; Sadowski, Ł. Ultrasonic Pulse Velocity Evaluation of the Pull-Off Adhesion between Epoxy Resin and Concrete Substrate. In Key Engineering Materials; Trans Tech Publications: Baech, Switzerland, 2017; Volume 728, pp. 390-395.

70. Szymanowski, J.; Sadowski, Ł. Adhesion assessment between concrete layers using the ultrasonic pulse velocity method. In Applied Mechanics and Materials; Trans Tech Publications: Baech, Switzerland, 2015; Volume 797, pp. 145-150.

71. Ongpeng, J.M.C.; Oreta, A.W.C.; Hirose, S. Contact and Noncontact Ultrasonic Nondestructive Test in Reinforced Concrete Beam. Adv. Civ. Eng. 2018, 2018. [CrossRef]

72. Michałek, J. Variation in Compressive Strength of Concrete across Thickness of Placed Layer. Materials 2019, 1213, 2162. [CrossRef] [PubMed]

73. Skowroński, W.; Stawiski, B. Ultrasonic evaluation regarding the effects of biological corrosion of historical roof trusses. In MATEC Web of Conferences; EDP Sciences: Les Ulis, France, 2019; Volume 284, p. 07006.

74. EN 13892-3:2005 Methods for Testing Materials for Undercoats—Part 3: Determination of Abrasion Resistance According to Bohme. Available online: http://sklep.pkn.pl/pn-en-13892-3-2015-02e.html (accessed on 16 March 2019).

75. EN 12504-2:2013-Testing Concrete in Structures-Part 2: Nondestructive Testing_-Determination of Rebound Number. Available online: http://sklep.pkn.pl/pn-en-12504-2-2013-03e.html (accessed on 16 March 2019).

76. Wong, H.S.; Head, M.K.; Buenfeld, N.R. Pore segmentation of cement-based materials from backscattered electron images. Cem. Concr. Res. 2006, 366, 1083-1090. [CrossRef]

77. Mohseni, E.; Miyandehi, B.M.; Yang, J.; Yazdi, M. A Single and combined effects of nano-SiO $\mathrm{O}_{2}, \operatorname{nano}_{-} \mathrm{Al}_{2} \mathrm{O}_{3}$ and nano-TiO2 on the mechanical, rheological and durability properties of self-compacting mortar containing fly ash. Constr. Build. Mater. 2015, 84, 331-340. [CrossRef]

78. Gowda, R.; Narendra, H.; Rangappa, D.; Prabhakar, R. Effect of nano-alumina on workability, compressive strength and residual strength at elevated temperature of Cement Mortar. Mater. Today Proc. 2017, 4, 12152-12156. [CrossRef]

79. Paul, S.C.; van Rooyen, A.S.; van Zijl, G.P.; Petrik, L.F. Properties of cement-based composites using nanoparticles: A comprehensive review. Constr. Build. Mater. 2018, 189, 1019-1034. [CrossRef]

80. Nazari, A.; Riahi, S. Improvement compressive strength of concrete in different curing media by $\mathrm{Al}_{2} \mathrm{O}_{3}$ nanoparticles. Mater. Sci. Eng. A 2011, 528, 1183-1191. [CrossRef]

81. Li, Z.; Wang, H.; He, S.; Lu, Y.; Wang, M. Investigations on the preparation and mechanical properties of the nano-alumina reinforced cement composite. Mater. Lett. 2006, 603, 356-359. [CrossRef]

82. Mohseni, E.; Tsavdaridis, K.D. Effect of nano-alumina on pore structure and durability of Class F Fly ash self-compacting mortar. Am. J. Eng. Appl. Sci. 2016, 9, 323-333. [CrossRef] 
83. Śliwiński, J. Wall effect-Essence of the phenomenon and the way of taking it into account in the concrete mix design. Cem. Lime Concr. 1998, 3, 151-154.

84. Stawiski, B. The heterogeneity of mechanical properties of concrete in formed constructions horizontally. Arch. Civ. Met. Eng. 2012, 121, 90-94. [CrossRef]

85. Stawiski, B. Ultradźwiękowe badania betonów i zapraw głowicami punktowymi. Prace Naukowe Instytutu Budownictwa Politechniki Wrocławskiej. Monografie 2009, 92, 154.

(C) 2019 by the authors. Licensee MDPI, Basel, Switzerland. This article is an open access article distributed under the terms and conditions of the Creative Commons Attribution (CC BY) license (http://creativecommons.org/licenses/by/4.0/). 